\title{
Global deposition of total reactive nitrogen oxides from 1996 to 2014 constrained with satellite observations of $\mathrm{NO}_{2}$ columns
}

\author{
Jeffrey A. Geddes ${ }^{1, \mathrm{a}}$ and Randall V. Martin ${ }^{1,2}$ \\ ${ }^{1}$ Department of Physics and Atmospheric Science, Dalhousie University, Halifax, Nova Scotia, Canada \\ ${ }^{2}$ Harvard-Smithsonian Center for Astrophysics, Cambridge, Massachusetts, USA \\ ${ }^{a}$ now at: Department of Earth and Environment, Boston University, Boston, Massachusetts, USA
}

Correspondence to: Jeffrey A. Geddes (jgeddes@bu.edu)

Received: 5 December 2016 - Discussion started: 2 January 2017

Revised: 28 May 2017 - Accepted: 11 July 2017 - Published: 29 August 2017

\begin{abstract}
Reactive nitrogen oxides $\left(\mathrm{NO}_{y}\right)$ are a major constituent of the nitrogen deposited from the atmosphere, but observational constraints on their deposition are limited by poor or nonexistent measurement coverage in many parts of the world. Here we apply $\mathrm{NO}_{2}$ observations from multiple satellite instruments (GOME, SCIAMACHY, and GOME2) to constrain the global deposition of $\mathrm{NO}_{y}$ over the last 2 decades. We accomplish this by producing top-down estimates of $\mathrm{NO}_{x}$ emissions from inverse modeling of satellite $\mathrm{NO}_{2}$ columns over 1996-2014, and including these emissions in the GEOS-Chem chemical transport model to simulate chemistry, transport, and deposition of $\mathrm{NO}_{y}$. Our estimates of long-term mean wet nitrate $\left(\mathrm{NO}_{3}^{-}\right)$deposition are highly consistent with available measurements in North America, Europe, and East Asia combined $(r=0.83$, normalized mean bias $=-7 \%, N=136$ ). Likewise, our calculated trends in wet $\mathrm{NO}_{3}^{-}$deposition are largely consistent with the measurements, with 129 of the 136 gridded modeldata pairs sharing overlapping $95 \%$ confidence intervals. We find that global mean $\mathrm{NO}_{y}$ deposition over 1996-2014 is $56.0 \mathrm{Tg} \mathrm{N} \mathrm{yr}^{-1}$, with a minimum in 2006 of $50.5 \mathrm{Tg} \mathrm{N}$ and a maximum in 2012 of $60.8 \mathrm{Tg}$ N. Regional trends are large, with opposing signs in different parts of the world. Over 1996 to 2014, $\mathrm{NO}_{y}$ deposition decreased by up to $60 \%$ in eastern North America, doubled in regions of East Asia, and declined by $20 \%$ in parts of western Europe. About $40 \%$ of the global $\mathrm{NO}_{y}$ deposition occurs over oceans, with deposition to the North Atlantic Ocean declining and deposition to the northwestern Pacific Ocean increasing. Using the residual between $\mathrm{NO}_{x}$ emissions and $\mathrm{NO}_{y}$ deposition over specific land regions, we investigate how $\mathrm{NO}_{x}$ export via atmospheric trans-
\end{abstract}

port has changed over the last 2 decades. Net export from the continental United States decreased substantially, from $2.9 \mathrm{Tg} \mathrm{N} \mathrm{yr}^{-1}$ in 1996 to $1.5 \mathrm{Tg} \mathrm{N} \mathrm{yr}^{-1}$ in 2014. Export from China more than tripled between 1996 and 2011 (from 1.0 to 3.5 $\mathrm{Tg} \mathrm{N} \mathrm{yr}^{-1}$ ), before a striking decline to $2.5 \mathrm{Tg} \mathrm{N} \mathrm{yr}^{-1}$ by 2014. We find that declines in $\mathrm{NO}_{x}$ export from some western European countries have counteracted increases in emissions from neighboring countries to the east. A sensitivity study indicates that simulated $\mathrm{NO}_{y}$ deposition is robust to uncertainties in $\mathrm{NH}_{3}$ emissions with a few exceptions. Our novel long-term study provides timely context on the rapid redistribution of atmospheric nitrogen transport and subsequent deposition to ecosystems around the world.

\section{Introduction}

The introduction of reactive nitrogen to the environment by anthropogenic activities (e.g., from fossil fuel combustion and the production of fertilizers for agriculture) has drastically altered the global nitrogen cycle with consequences throughout the Earth system (Galloway et al., 2004). Reactive nitrogen dominates the chemical production of tropospheric ozone and contributes to inorganic aerosol formation, with implications for air quality and climate. Deposition of nitrogen from the atmosphere has been linked to eutrophication and acidification (Bouwman et al., 2002), reductions in biodiversity (Bobbink et al., 2010; Hernández et al., 2016; Isbell et al., 2013; De Schrijver et al., 2011), and climate impacts through coupling with the carbon cycle and greenhouse gas emissions (Liu and Greaver, 2009; Reay et al., 
2008; Templer et al., 2012). Despite its global importance, observational constraints on nitrogen deposition are lacking in many parts of the world due to poor or nonexistent measurement coverage (Vet et al., 2014).

Atmospheric transport is a dominant process for distributing reactive nitrogen around the world (Galloway et al., 2008). Some forms of reactive nitrogen can be transported over distances greater than $1000 \mathrm{~km}$ (Neuman et al., 2006; Sanderson et al., 2008), depositing across national boundaries and continents. For example, the US is estimated to export $30-40 \%$ of its reactive nitrogen emissions (Dentener et al., 2006; Holland et al., 2005; Zhang et al., 2012), while transport from China accounts for up to 66-92\% of total nitrogen deposition to parts of the northwestern Pacific Ocean (Zhao et al., 2015). Fertilization of the open ocean due to atmospheric transport and deposition of anthropogenic nitrogen may be a considerable factor in marine productivity (Duce et al., 2008), prompting important questions about the fate and impact of deposition far downwind of sources where observations are limited.

Reactive nitrogen oxides $\left(\mathrm{NO}_{y} \equiv \mathrm{NO}+\mathrm{NO}_{2}+\mathrm{HNO}_{3}+\right.$ $\mathrm{HONO}+$ organic nitrate molecules + aerosol nitrate) contribute about half of the total nitrogen deposited worldwide (Dentener et al., 2006). $\mathrm{NO}_{y}$ deposition was estimated to be around $45-50 \mathrm{Tg} \mathrm{N} \mathrm{yr}^{-1}$ in the late 1990 s and early 2000s, representing a three- to fourfold increase since the preindustrial era (Dentener et al., 2006; Kanakidou et al., 2016; Lamarque et al., 2013). A substantial range exists in the trajectory of global $\mathrm{NO}_{y}$ deposition beyond the year 2000, depending on the emission scenario. Galloway et al. (2004) projected that $\mathrm{NO}_{y}$ deposition could increase by $>70 \%$ by 2050, while Dentener et al. (2006) projected changes between -25 to $+50 \%$ by 2030 for maximum feasible reduction and "pessimistic" scenarios, respectively. More recent multimodel projections by Lamarque et al. (2013) estimate $\mathrm{NO}_{y}$ deposition would change by -16 to $+5 \%$ for 2030 and by -48 to $-25 \%$ for 2100 , depending on the representative concentration pathway (RCP) scenario. This range in projections highlights the need for global observational constraints on contemporary changes in nitrogen oxide emissions.

Sources of $\mathrm{NO}_{x}\left(\equiv \mathrm{NO}+\mathrm{NO}_{2}\right)$, whose oxidation is responsible for the formation of other reactive nitrogen oxides, include fossil fuel combustion, biomass burning, lightning, and biogenic emission from soil. The magnitude and spatial distribution of $\mathrm{NO}_{x}$ emissions have changed considerably over the past several decades, corresponding to patterns of human development and emission control measures. Tropospheric $\mathrm{NO}_{2}$ columns derived from satellite remote sensing observations have been used extensively to constrain regional and global $\mathrm{NO}_{x}$ emissions (Streets et al., 2013). This top-down approach complements bottom-up inventories that are assembled using regionally specific emission factors and fuel combustion data for various source categories. In particular, satellite $\mathrm{NO}_{2}$ observations can provide insight into otherwise poorly constrained sources (Beirle et al., 2010; Jae- gle et al., 2005; Richter et al., 2004; Vinken et al., 2014), produce coherent long-term trends (van der A et al., 2008; Lu et al., 2015; Stavrakou et al., 2008; Zhang et al., 2007), document interannual variability (Castellanos and Boersma, 2012; Konovalov et al., 2010; Russell et al., 2012), offer information to evaluate and improve bottom-up inventories on the global scale (Martin, 2003; Miyazaki et al., 2017), and provide timely emission updates (Lamsal et al., 2011; Mijling et al., 2013; Souri et al., 2016).

Satellite observations of $\mathrm{NO}_{2}$ began with GOME (19952003), were followed by SCIAMACHY (2002-2011), and continue today with OMI (2004-), GOME-2 (2007-), and TROPOMI (2017-), resulting in a record of global atmospheric $\mathrm{NO}_{2}$ abundance over the past 20 years. These observations have been used previously to estimate the deposition of nitrogen species, either in combination with chemical transport modeling or with empirical approaches (Cheng et al., 2013; Jia et al., 2016; Lu et al., 2013; Nowlan et al., 2014). For example, Nowlan et al. (2014) demonstrated how satellite-inferred surface concentrations of $\mathrm{NO}_{2}$ can be combined with modeling to produce spatially continuous estimates of $\mathrm{NO}_{2}$ dry deposition fluxes. They found that dry deposition of $\mathrm{NO}_{2}$ contributes as much as $85 \%$ of total $\mathrm{NO}_{y}$ deposition in urban areas, but represents only $3 \%$ of global $\mathrm{NO}_{x}$ emitted. The remaining $97 \%$ of global $\mathrm{NO}_{y}$ deposition is made up of both wet and dry deposition of other reactive nitrogen oxide compounds that are not directly observed by satellite-based instruments.

In this study, we expand on the approach of Nowlan et al. (2014) by using the satellite observations of $\mathrm{NO}_{2}$ columns to constrain total $\mathrm{NO}_{y}$ deposition, including other oxidized nitrogen species and wet deposition which contribute substantially to $\mathrm{NO}_{y}$ deposition. We accomplish this by constraining surface $\mathrm{NO}_{x}$ emissions using the satellite observations of $\mathrm{NO}_{2}$ and simulating subsequent $\mathrm{NO}_{y}$ deposition with a global chemical transport model. Given the effective mass balance between $\mathrm{NO}_{x}$ emissions and deposition of reactive nitrogen oxides, observational constraints on $\mathrm{NO}_{x}$ emissions provide a powerful top-down constraint on deposition (which to our knowledge has not yet been exploited in this way).

We leverage the long-term coverage of GOME, SCIAMACHY, and GOME-2 observations to produce a globally consistent and continuous record of $\mathrm{NO}_{y}$ deposition from 1996 to 2014. We highlight long-term trends in satelliteconstrained $\mathrm{NO}_{y}$ deposition around the world and discuss changes in regional export of $\mathrm{NO}_{x}$. Our satellite-constrained estimates of $\mathrm{NO}_{y}$ deposition are evaluated using measured wet nitrate $\left(\mathrm{NO}_{3}^{-}\right)$deposition from a variety of sources worldwide. We also explore the sensitivity of the $\mathrm{NO}_{y}$ deposition estimates to uncertainties in $\mathrm{NH}_{3}$ emissions and discuss other considerations. 


\section{Methods}

\subsection{Satellite-based constraints on $\mathrm{NO}_{y}$ deposition}

The application of satellite $\mathrm{NO}_{2}$ column observations to constrain $\mathrm{NO}_{y}$ deposition requires a method to propagate the observational information across the entire $\mathrm{NO}_{y}$ system containing species with lifetimes of days or longer. The short $\mathrm{NO}_{x}$ lifetime of hours during daytime satellite observations implies that a direct assimilation for $\mathrm{NO}_{2}$ column abundance would rapidly lose the observational information as the assimilation returns to its unperturbed state well before the next satellite observation days later. We therefore apply satellite $\mathrm{NO}_{2}$ observations to constrain $\mathrm{NO}_{x}$ emissions in a simulation of $\mathrm{NO}_{y}$ deposition so the information propagates across the entire $\mathrm{NO}_{y}$ system.

We calculate top-down surface $\mathrm{NO}_{x}$ emissions from 1996 to 2014 using observations from GOME (19952003), SCIAMACHY (2002-2011) and GOME-2 (2007-). The similar overpass time of these three instruments (from about 09:30 to 10:30 LT, local time) facilitates their combination to provide consistent long-term coverage (Geddes et al., 2015; Hilboll et al., 2013; Konovalov et al., 2010; van der A et al., 2008). We achieve consistency across all three instruments despite their varying pixel sizes $(320 \mathrm{~km} \times 40 \mathrm{~km}, 60 \mathrm{~km} \times 30 \mathrm{~km}$, and $80 \mathrm{~km} \times 40 \mathrm{~km}$ for GOME, SCIAMACHY, and GOME-2, respectively) by gridding the daily observations from each to a regular coarse grid of $2^{\circ} \times 2.5^{\circ}$ latitude by longitude. Tropospheric $\mathrm{NO}_{2}$ vertical column densities are provided by KNMI at http://www.temis. nl/airpollution/. In all cases, $\mathrm{NO}_{2}$ column densities are retrieved by differential optical absorption spectroscopy using backscattered radiance in the $425-450 \mathrm{~nm}$ wavelength range according to the retrieval algorithm documented in Boersma et al. (2004). The error in individual satellite-derived tropospheric $\mathrm{NO}_{2}$ column retrievals is estimated to be around 35$60 \%$ for polluted scenes and greater than $100 \%$ for clean regions (Boersma et al., 2004). Boersma et al. (2016) describe well the value of accounting for vertically resolved instrument sensitivity. We use the averaging kernels provided with the data to replace a priori $\mathrm{NO}_{2}$ vertical profiles with those from GEOS-Chem model following Lamsal et al. (2010). We use daily nadir observations with a cloud radiance fraction of less than 0.5 . We minimize errors associated with wintertime retrievals by using a solar zenith angle cut-off of $50^{\circ}$.

We use the GEOS-Chem chemical transport model (www. geos-chem.org) v9-02 to conduct the inversion of satellite observations of $\mathrm{NO}_{2}$ and constrain global $\mathrm{NO}_{y}$ deposition. The simulation is described in Appendix A. Briefly, GEOSChem is driven by assimilated meteorology from the NASA Global Modeling and Assimilation Office and simulates detailed $\mathrm{HO}_{x}-\mathrm{NO}_{x}-\mathrm{VOC}-$ aerosol (VOC: volatile organic compound) chemistry (Bey et al., 2001; Park et al., 2004). Removal occurs through wet deposition (Amos et al., 2012; Liu et al., 2001) and dry deposition based on the widely used resistance-in-series formulation (Wesely, 1989). Anthropogenic, biogenic, soil, lightning, and biomass burning emissions are included (see Appendix A). In the case of $\mathrm{NO}_{x}$, the bottom-up emissions are used as prior estimates that we then overwrite with the top-down emissions.

We adopt a finite-difference mass-balance inversion (Cooper et al., 2017; Lamsal et al., 2011) for computational expedience given the 19-year period of interest. In two initial simulations, a perturbation ( $30 \%)$ to the a priori emissions, $E$, in a grid cell is used to find the relationship between the a priori $\mathrm{NO}_{2}$ column, $\Omega$, and the change in the column resulting from that perturbation:

$\frac{\Delta E}{E}=\beta \times \frac{\Delta \Omega}{\Omega}$.

The factor $\beta$ in Eq. (1) accounts for nonlinear feedbacks between a change in $\mathrm{NO}_{x}$ emissions and $\mathrm{NO}_{x}$ chemistry in a grid cell leading to grid cell $\mathrm{NO}_{2}$ column abundance.

We then use monthly-mean gridded satellite observations, $\Omega_{\text {sat }}$, in combination with monthly $\beta$ values for each grid box to derive new gridded annual emissions, $E_{\text {topdown }}$, from the prior emissions estimates, $E_{\text {prior }}$, by rewriting Equation 1 as:

$E_{\text {topdown }}=E_{\text {prior }} \cdot\left[1+\beta \frac{\Omega_{\mathrm{sat}}-\Omega_{\text {prior }}}{\Omega_{\text {prior }}}\right]$.

We use GOME observations for years 1996 to 2002, SCIAMACHY observations for years 2003 to 2006, and GOME-2 observations for years 2007 to 2014. In all cases, monthly mean simulated $\mathrm{NO}_{2}$ columns are calculated using days with coincident satellite observations. The simulated $\mathrm{NO}_{2}$ vertical column is output daily for late morning. We calculate scaling factors for every month with available satellite observations, then calculate an annual mean scaling factor that is used to infer annual mean top-down emissions. Our top-down emissions retain the same seasonality as the prior emissions to mitigate concerns about seasonally missing data (such as from snow or monsoonal clouds). The top-down emissions are then used in a final simulation to model $\mathrm{NO}_{y}$ deposition. For locations without any satellite observations, the a priori emissions are used. The resultant simulation of $\mathrm{NO}_{y}$ deposition is thus constrained by, and consistent with, the satellite $\mathrm{NO}_{2}$ observations (similar in essence to an assimilation system). We note that uncertainty in tropospheric $\mathrm{NO}_{2}$ from lightning will propagate into the inversion (Travis et al., 2016), but there is no evidence of a significant trend in lightning $\mathrm{NO}_{x}$ over the long term (Murray et al., 2012). A constant bias is unlikely to affect the trend analyses presented here.

Table 1 shows the annual global top-down $\mathrm{NO}_{x}$ emissions we obtain from our calculations. We derive global mean satellite-constrained $\mathrm{NO}_{x}$ emissions from 1996 to 2014 of $55.6 \pm 3.4 \mathrm{Tg} \mathrm{N} \mathrm{yr}^{-1}$. Our top-down global $\mathrm{NO}_{x}$ emissions for 2001 of $52.3 \mathrm{Tg} \mathrm{N}$ are consistent with the mean \pm standard deviation from over 20 models used in the Coordi- 
Table 1. Global top-down $\mathrm{NO}_{x}$ emissions calculated using the finite mass-balance inversion approach with observations from GOME, SCIAMACHY, and GOME-2.

\begin{tabular}{cr}
\hline Year & $\begin{array}{r}\text { Global NO} \\
\text { emissions } \\
\left(\mathrm{Tg} \mathrm{N} \mathrm{yr}^{-1}\right)^{*}\end{array}$ \\
\hline 1996 & 60.1 \\
1997 & 58.4 \\
1998 & 59.2 \\
1999 & 59.6 \\
2000 & 53.4 \\
2001 & 52.3 \\
2002 & 55.1 \\
2003 & 50.1 \\
2004 & 51.5 \\
2005 & 51.2 \\
2006 & 50.0 \\
2007 & 54.7 \\
2008 & 56.1 \\
2009 & 55.9 \\
2010 & 57.5 \\
2011 & 58.9 \\
2012 & 59.3 \\
2013 & 58.5 \\
2014 & 54.0 \\
Mean & 55.6 \\
\hline * Includes anthropogenic $\mathrm{HNO}_{3}$ \\
flux of $2.3 \pm 0.1 \mathrm{Tg} \mathrm{N}^{-1}$. \\
\hline
\end{tabular}

nated Model Studies Activities of the Task Force on Hemispheric Transport of Air Pollution (HTAP) for the same year of $46.6 \pm 7.8 \mathrm{Tg} \mathrm{N}$ (Vet et al., 2014).

\subsection{Measurements of wet deposition}

We use a variety of regional and global measurements of wet nitrate $\left(\mathrm{NO}_{3}^{-}\right)$deposition to evaluate our satellite-constrained simulation from 1996 to 2014.

To evaluate overall global performance we use data compiled by the World Data Centre for Precipitation Chemistry for two time periods: 2000-2002 and 2005-2007 (http: //www.wdcpc.org/). The use of these data ensures optimal and consistent quality standards across all stations, allowing for evaluation of global performance with careful consideration of sampling protocols and data completeness (Vet et al., 2014).

To evaluate the long-term means and trends from 1996 to 2014, we obtain observations of wet $\mathrm{NO}_{3}^{-}$deposition from North America, Europe, and East Asia where continuous measurements are available throughout most of our study period. Observations come from the National Atmospheric Deposition Program in the United States (http://nadp.sws.uiuc. edu/, available 1996-2014), from the Canadian Air and Precipitation Monitoring Network in Canada (http://www.ec.gc.

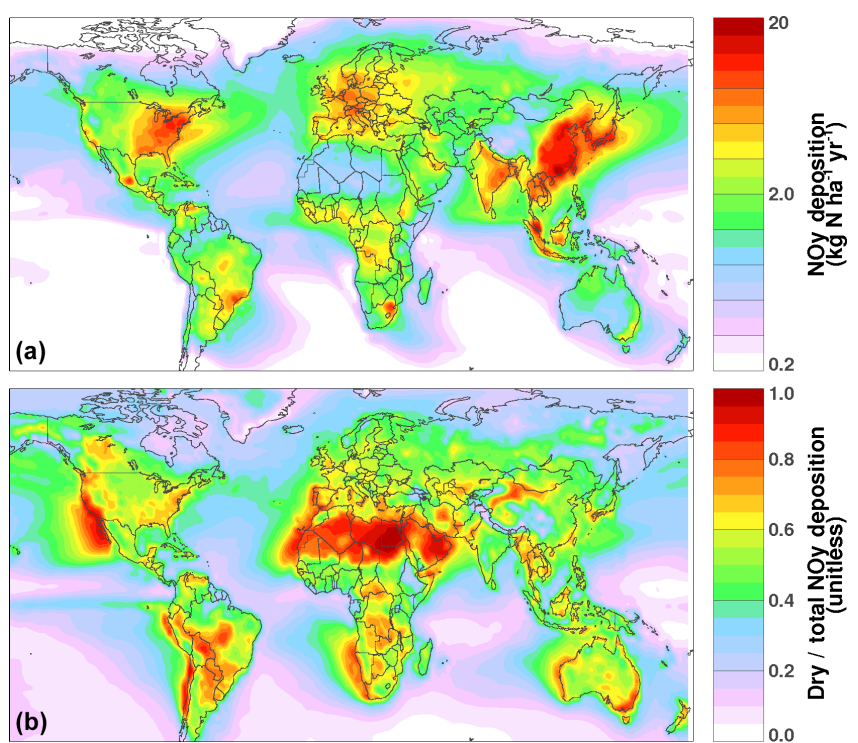

Figure 1. Long-term (1996-2014) mean $\mathrm{NO}_{y}$ deposition derived from the GEOS-Chem simulation, constrained by satellite observations of $\mathrm{NO}_{2}$ columns from the GOME, SCIAMACHY, and GOME-2 instruments (a). Mean ratio of simulated dry $\mathrm{NO}_{y}$ deposition to total $\mathrm{NO}_{y}$ deposition (b).

ca/rs-mn/, available 1996-2011), from the European Monitoring and Evaluation Programme in Europe (http://www. emep.int/, available 1996-2014) and from the Acid Deposition Monitoring Network in East Asia (http://www.eanet. asia, available 2000-2014). In the US and Canada, wet deposition is measured by wet-only samplers that are triggered at the onset of precipitation. Measurements in Europe are made by bulk- and wet-only sampling methods, and we used both in this analysis. Measurements across East Asia are reported as wet-only, although at some stations this may not be accomplished by strictly wet-only samplers (http://www.eanet. asia/product/manual/prev/techwet.pdf).

For our trend analysis, we only included stations which had quality controlled annual data for at least 15 of the 19 years in our study. This left 128 stations across the United States, 14 stations in Canada, 18 stations across Europe, and 14 stations across East Asia. For comparison with the GEOSChem model, if multiple stations are available within a single grid box we grid all measurements of annual wet deposition to the model horizontal resolution.

\section{Satellite-constrained estimates of $\mathrm{NO}_{y}$ deposition}

Here we summarize the overall patterns in long-term mean deposition resulting from our satellite-constrained simulation, followed by a discussion of the long-term trends, changes in regional export, and the sensitivity of the simulated $\mathrm{NO}_{y}$ deposition to potential uncertainties in $\mathrm{NH}_{3}$ emissions and other considerations. 


\subsection{Long-term mean $\mathrm{NO}_{y}$ deposition}

Figure 1 (top) shows our satellite-constrained long-term mean $\mathrm{NO}_{y}$ deposition from 1996 to 2014 . We find that $32.2 \mathrm{Tg} \mathrm{N} \mathrm{yr}^{-1}$ is deposited on average over the continents ( $57 \%$ of the total), and $23.8 \mathrm{Tg} \mathrm{N} \mathrm{yr}^{-1}$ is deposited on average over the oceans ( $43 \%$ of the total). This is similar to the estimate by Galloway et al. (2004) that $46 \%$ of modern day $\mathrm{NO}_{y}$ deposition occurs over the oceans. Critical nitrogen deposition loads for various natural freshwater and terrestrial ecosystems lie in the range of 5$20 \mathrm{~kg} \mathrm{Nha}^{-1} \mathrm{yr}^{-1}$, depending on the ecosystem, soil conditions, and land history (World Health Organization, 2000). We estimate that mean deposition of oxidized nitrogen alone exceeds $5 \mathrm{~kg} \mathrm{Nha}^{-1} \mathrm{yr}^{-1}$ over a land area of approximately $12.7 \times 10^{6} \mathrm{~km}^{2}$ (or $\sim 8 \%$ total land area).

In the Northern Hemisphere, high $\mathrm{NO}_{y}$ deposition tends to be associated with regions that have high anthropogenic $\mathrm{NO}_{x}$ sources. We find that mean $\mathrm{NO}_{y}$ deposition in the eastern United States exceeds $10 \mathrm{~kg} \mathrm{Nha}^{-1} \mathrm{yr}^{-1}$ (maximum $=11.4 \mathrm{~kg} \mathrm{~N} \mathrm{ha}^{-1} \mathrm{yr}^{-1}$ ) with elevated deposition extending into southeastern Canada and hundreds of kilometers into the Atlantic Ocean. This is similar to the multimodel ensemble results from ACCMIP and HTAP, predicting between 5 and $15 \mathrm{~kg} \mathrm{Nha}^{-1} \mathrm{yr}^{-1}$ in this region (Lamarque et al., 2013; Vet et al., 2014). A prior GEOS-Chem analysis over North America for the years 2006-2008 also predicted $\mathrm{NO}_{y}$ deposition exceeding $10 \mathrm{~kg} \mathrm{Nha}^{-1} \mathrm{yr}^{-1}$ in the eastern US (Zhang et al., 2012). Elsewhere in North America, we find high $\mathrm{NO}_{y}$ deposition along the western coast of California (up to $6 \mathrm{~kg} \mathrm{Nha}^{-1} \mathrm{yr}^{-1}$ ) and in the vicinity of Mexico City (up to $10 \mathrm{~kg} \mathrm{Nha}^{-1} \mathrm{yr}^{-1}$ ).

We find mean $\mathrm{NO}_{y}$ deposition is also elevated throughout Europe, with a maximum of $8.5 \mathrm{~kg} \mathrm{Nha}^{-1} \mathrm{yr}^{-1}$ located in northern Italy near the Po Valley region. Again, our long-term estimate in this region is similar to the ACCMIP and HTAP ensemble means, predicting $\mathrm{NO}_{y}$ deposition in the range of $5-10 \mathrm{~kg} \mathrm{Nha}^{-1} \mathrm{yr}^{-1}$ (Lamarque et al., 2013; Vet et al., 2014). The elevated deposition here is also spatially consistent with the results from Holland et al. (2005). We find high deposition extending into western Russia with a hotspot in the vicinity of Moscow approaching $5 \mathrm{~kg} \mathrm{Nha}^{-1} \mathrm{yr}^{1}$. Our observation-constrained estimate also has isolated regions of high deposition in the Middle East (around $4-5 \mathrm{~kg} \mathrm{Nha}^{-1} \mathrm{yr}^{-1}$ in the vicinity of Tehran and around the Persian Gulf).

We find that the highest mean deposition in the world occurs in China, exceeding $10 \mathrm{~kg} \mathrm{Nha}^{-1} \mathrm{yr}^{-1}$ in many regions. High deposition extends into the midlatitude western Pacific Ocean off the coast of East Asia. $\mathrm{NO}_{y}$ deposition in the ACCMIP and HTAP ensemble means also exceeds $10 \mathrm{~kg} \mathrm{Nha}^{-1} \mathrm{yr}^{-1}$ throughout eastern China. We find the highest long-term mean deposition (with a maximum close to $20 \mathrm{~kg} \mathrm{Nha}^{-1} \mathrm{yr}^{-1}$ ) occurs in the south, around the Pearl River Delta and in the vicinity of Guangzhou, although deposition is also high in the regions just west of Beijing and Shanghai.

In the Southern Hemisphere, high $\mathrm{NO}_{y}$ deposition is associated with biomass burning and soil $\mathrm{NO}_{x}$ sources, in addition to anthropogenic sources. For example, we find $\mathrm{NO}_{y}$ deposition is between 3 and $5 \mathrm{~kg} \mathrm{Nha}^{-1} \mathrm{yr}^{-1}$ in central and southern Brazil as well as in the tropical rainforests and moist savannahs of Africa. Our estimates in these biomassburning- and soil- $\mathrm{NO}_{x}$-dominated regions are also generally consistent with the ACCMIP and HTAP ensemble estimates $\left(2-5 \mathrm{~kg} \mathrm{Nha}^{-1} \mathrm{yr}^{-1}\right)$. We find $\mathrm{NO}_{y}$ deposition up to $10 \mathrm{~kg} \mathrm{Nha}^{-1} \mathrm{yr}^{-1}$ in the vicinity of São Paulo and Rio de Janeiro, and in the vicinity of Johannesburg and the industrialized Mpumalanga Highveld of South Africa (all dominated by anthropogenic $\mathrm{NO}_{x}$ emissions). Our constrained simulation also identifies hotspots of deposition in the vicinity of Melbourne and Sydney, Australia $\left(\sim 4 \mathrm{~kg} \mathrm{~N} \mathrm{ha}^{-1} \mathrm{yr}^{-1}\right)$.

Figure 1 (bottom) shows the simulated long-term ratio of dry $\mathrm{NO}_{y}$ deposition to total (wet + dry) $\mathrm{NO}_{y}$ deposition. Globally, dry and wet deposition contribute roughly equally to total $\mathrm{NO}_{y}$ deposition (52 and $48 \%$, respectively). Dry deposition usually accounts for more than $50 \%$ of the total over the continents and directly offshore, whereas wet deposition dominates over the remote oceans. In the generally arid regions of the world (e.g., the southwestern US, the Sahara Desert, the Arabian Peninsula, and the Gobi Desert) dry deposition accounts for $\sim 85 \%$ or more of the total deposition. Elsewhere, dry deposition fractions tend to be highest $(>60 \%)$ nearest to major surface $\mathrm{NO}_{x}$ sources (e.g., the eastern US, western Europe, and near other major urban centers around the world in addition to the soil- and biomassburning-dominated source regions in South America and Africa). $\mathrm{HNO}_{3}$ typically makes the dominant contribution to dry $\mathrm{NO}_{y}$ deposition, although $\mathrm{NO}_{2}$ and $\mathrm{HNO}_{3}$ can make almost equal contributions in certain high- $\mathrm{NO}_{x}$ environments. Isoprene nitrates and peroxyacetyl nitrates comprise $\sim 10$ $30 \%$ of dry $\mathrm{NO}_{y}$ deposition in some densely forested and high-latitude environments, respectively.

We evaluate our estimates of $\mathrm{NO}_{y}$ deposition with measured wet $\mathrm{NO}_{3}^{-}$from several sources. Figure 2 shows measurements of annual wet $\mathrm{NO}_{3}^{-}$deposition from the World Data Centre for Precipitation Chemistry, available for two time periods: 2000-2002 $(N=470)$ and 2005-2007 $(N=484)$. In both we see the patterns of elevated deposition in eastern North America, western Europe, and parts of South and East Asia, with lower deposition in western North America, across high latitudes in the Northern Hemisphere, and in the available observations in Africa. High deposition in the Southern Hemisphere is observed between São Paulo and Rio de Janeiro, and just southeast of Johannesburg. Figure 2 also shows the wet $\mathrm{NO}_{3}^{-}$deposition from our constrained simulation during the same two time periods (2000-2002 and 2005-2007), which exhibits similar patterns to those found in total $\mathrm{NO}_{y}$ deposition (Fig. 1). 

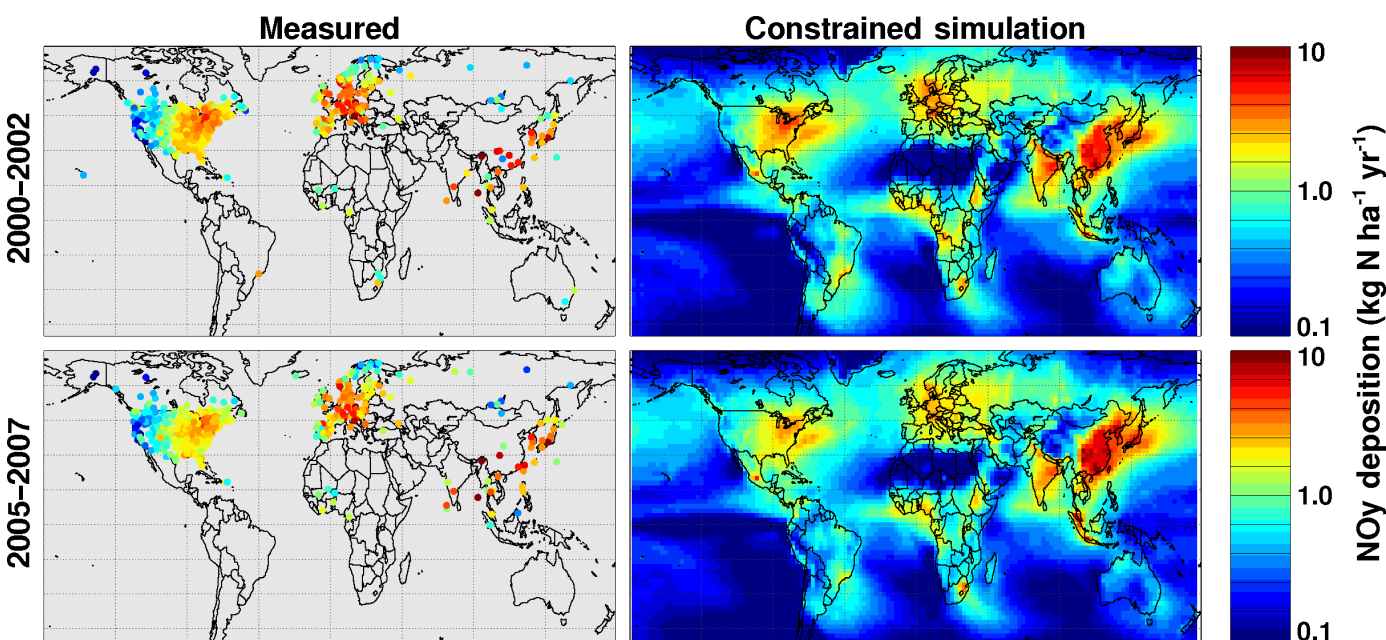

Figure 2. Annual wet $\mathrm{NO}_{3}^{-}$deposition from measurements available through the World Data Centre for Precipitation Chemistry and from the GEOS-Chem simulation constrained with satellite observations of $\mathrm{NO}_{2}$. Two time periods are represented: 2000-2002 and 2005-2007.
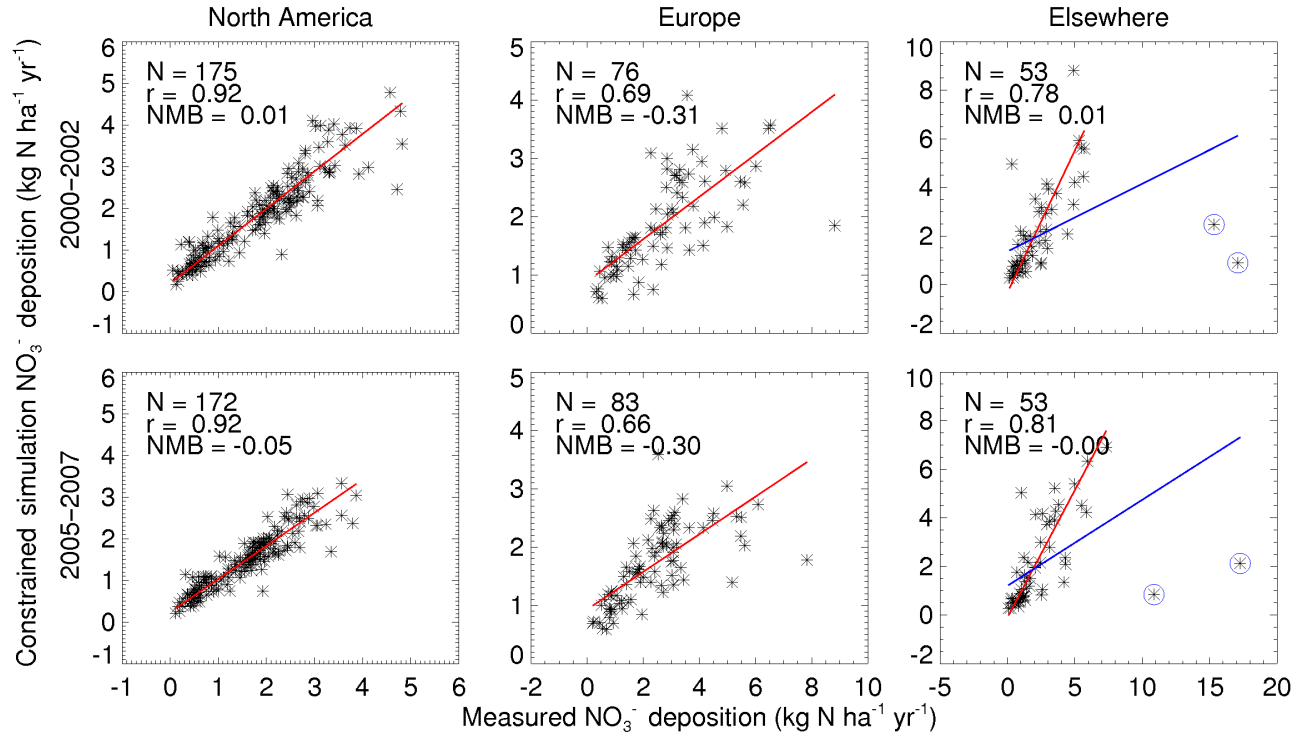

Figure 3. Scatter plot of the satellite-constrained simulated wet $\mathrm{NO}_{3}^{-}$deposition vs. measurements available through the World Data Centre for Precipitation Chemistry for specific subsets of the data. The red lines show the result of a reduced major axis linear regression. In the right column, the blue line shows the fit across all data and the red line shows the fit excluding the two circled data points that are discussed in the text (reported statistics refer to the red line fit).

We find a high degree of consistency between our estimate and the observations for both 2000-2002 $(N=306$ modeldata pairs) and 2005-2007 ( $N=310$ model-data pairs); the normalized mean bias (NMB) is -14 and $-16 \%$, respectively. The vast majority of pairs $(>80 \%)$ agree to within $50 \%$ of each other. Figure 3 shows scatter plots for specific subsets of the global data. The agreement for both time periods is strongest over North America $(r=0.92$ for both 2000-2002 and 2005-2007, $\mathrm{NMB}=+1.0$ and $-5.0 \%$, respectively). Robust model agreement with wet nitrate deposition observations over densely monitored North America is characteristic of other global studies (Dentener et al., 2006; Lamarque et al., 2013; Vet et al., 2014). Our agreement is also good in Europe $(r=0.69$ and 0.66, and NMB $=-31.0$ and $-29.8 \%$, respectively). The weaker correlation and low bias in this region is likewise characteristic of global studies, although our spatial correlation $(r=0.66-0.69)$ is on the high end of previously reported multimodel ensembles $(r \sim 0.4-0.6$, Dentener et al., 2006; Lamarque et al., 2013; Vet et al., 2014). The negative bias over Europe compared to North America has previously been attributed to poor modeling of precipitation and/or spatial representativeness of 
the measurements compared to model resolution. Throughout the rest of the world (encompassing observations mostly over Asia, but also over eastern Russia, and some locations in the Southern Hemisphere) the combined spatial coverage of the observations is very low $(N=53)$. Normalized mean bias in these estimates is also high compared to North America $(\mathrm{NMB}=-19.5$ and $-17.8 \%$ for $2000-2002$ and $2005-$ 2007 , respectively), and our spatial correlation with the measurements is weak ( $r=0.35$ and 0.42 , respectively). We find that our poor agreement here is disproportionately driven by the two observations that also have the highest measured deposition in the world: near Port Blair on the South Andaman Island in the Bay of Bengal, and in the Arunachal Pradesh state in northeastern India. Agreement is considerably better with the rest of the data $(r=0.78$ and $0.72, \mathrm{NMB}=+0.01$ and $-0.01 \%$ for 2000-2002 and 2005-2007, respectively). Excluding these two points substantially improves the global agreement as well (from $r=0.57$ to 0.75 and $r=0.59$ to 0.75 , respectively). Site representativeness, precipitation errors, or uncertainty in our satellite-constrained $\mathrm{NO}_{x}$ emissions may explain the discrepancy at these two specific sites.

In addition to global data for 2000-2002 and 2005-2007 from the World Data Centre for Precipitation Chemistry, we also evaluate our estimates of $\mathrm{NO}_{y}$ deposition over the long term (1996-2014) using continuous observations provided by regional networks. Figure 4 shows measured wet $\mathrm{NO}_{3}^{-}$ deposition over North America, Europe, and East Asia for locations where at least 15 years of quality-controlled annual data are available. These long-term mean observations demonstrate many of the same spatial patterns as the time slices from 2000-2002 and 2005-2007. In North America, a relatively smooth gradient is observed from low deposition in the west to high deposition at sites in the east. In Europe, the highest measured long-term mean wet $\mathrm{NO}_{3}^{-}$deposition occurs at a coastal site in southern Norway, at a site just east of Copenhagen, and at locations in northern Italy and in Switzerland. At higher-latitude sites, deposition is lower. Across the eastern Asia network, the measurements show the highest deposition at sites in Southeast Asia (e.g., at a location between Kuala Lumpur and Singapore, and another in the vicinity of Jakarta) and in Japan. The lowest long-term mean deposition occurs at high-latitude sites along the border of Russia and Mongolia, while moderate to high deposition is measured on the coast of eastern China.

In general, our satellite-constrained estimate reflects the spatial variability that is seen in the measurements. Globally, the correlation between measured $\mathrm{NO}_{3}^{-}$deposition and our estimated wet $\mathrm{NO}_{3}^{-}$deposition is excellent $(r=0.83$, $\mathrm{NMB}=-7.7 \%, N=136$ gridded model-data pairs). The vast majority of pairs $(>85 \%)$ agree to within $50 \%$ of each other. For the individual regions, normalized mean bias in our estimate is the smallest over North America $(\mathrm{NMB}=+2.4 \%)$, and higher over Europe and East Asia $(\mathrm{NMB}=-32$ and $-25 \%$, respectively). The spatial corre- lation over each region is strong ( $r=0.89, r=0.87$, and $r=0.69$ for North America, Europe, and East Asia, respectively), but sample sizes over Europe $(N=16)$ and East Asia $(N=11)$ are small so we emphasize caution in the interpretation of the statistics for these two regions. The lack of continuous measurement coverage even in parts of the world with routine network observations highlights the imperative of using other novel observational constraints on deposition (such as the global satellite observations of $\mathrm{NO}_{2}$ used here).

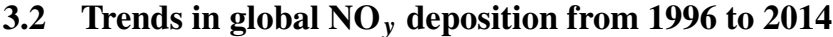

Our long-term satellite-constrained estimate of $\mathrm{NO}_{y}$ deposition facilitates a unique and up-to-date investigation of the changes in $\mathrm{NO}_{y}$ deposition around the world. We calculate linear trends in annual $\mathrm{NO}_{y}$ deposition using the nonparametric Sen's method (Sen, 1968) and test for significance with the nonparametric Mann-Kendall method (Kendall, 1975; Mann, 1945). We treat increasing or decreasing trends as significant if $p<0.01$. Given that this is a test for linear trends, regions where shorter-term trends in deposition may have changed signs over the period of study could result in erroneous or insignificant trends. Below we discuss particular regions where this is the case.

Figure 5 shows the long-term annual and seasonal trends calculated from our satellite-constrained estimate of total $\mathrm{NO}_{y}$ deposition across 1996-2014 (hatching indicates statistical significance). Figure 6 highlights time series of total $\mathrm{NO}_{y}$ deposition over three specific regions covering parts of North America, western Europe, and East Asia (as outlined in dashed boxes in Fig. 5a).

Substantial decreases are seen throughout North America, extending over the Atlantic Ocean to remote regions. The time series for this region (Fig. 6, left) shows that $\mathrm{NO}_{y}$ deposition decreased by almost $40 \%$ from $6.4 \mathrm{Tg} \mathrm{N} \mathrm{yr}^{-1}$ in $1996-1998$ to $3.9 \mathrm{Tg} \mathrm{Nyr}^{-1}$ in $2012-2014$. The steepest local decline in the world appears over the Ohio River Valley area, with a maximum near Pittsburgh where $\mathrm{NO}_{y}$ deposition decreased by $-0.6 \mathrm{~kg} \mathrm{~N}^{-1} \mathrm{yr}^{-2}$. $\mathrm{NO}_{y}$ deposition near Pittsburgh decreased from consistently exceeding $15 \mathrm{~kg} \mathrm{Nha}^{-1} \mathrm{yr}^{-1}$ during 1996-2000, to below $6 \mathrm{~kg} \mathrm{~N} \mathrm{ha}^{-1} \mathrm{yr}^{-1}$ by 2014 . The strong decrease in the northeast is consistent with other long-term observational studies for the US (Sickles and Shadwick, 2007, 2015). Studies of US $\mathrm{NO}_{x}$ emissions derived from satellite observations have also highlighted the remarkable success of emission controls (Duncan et al., 2013; Russell et al., 2012). Our constrained estimate has the steepest declines during the summer (Fig. 5; June, July, and August, JJA), restricted tightly to the source regions. This also agrees with long-term observations showing the strongest reductions in the summer (Sickles and Shadwick, 2015), consistent with the shorter lifetime of $\mathrm{NO}_{x}$ and efficient dry deposition of $\mathrm{NO}_{y}$ over the forested eastern US. We find significant decreases far downwind over the Atlantic Ocean during the other months, when $\mathrm{NO}_{y}$ can be 

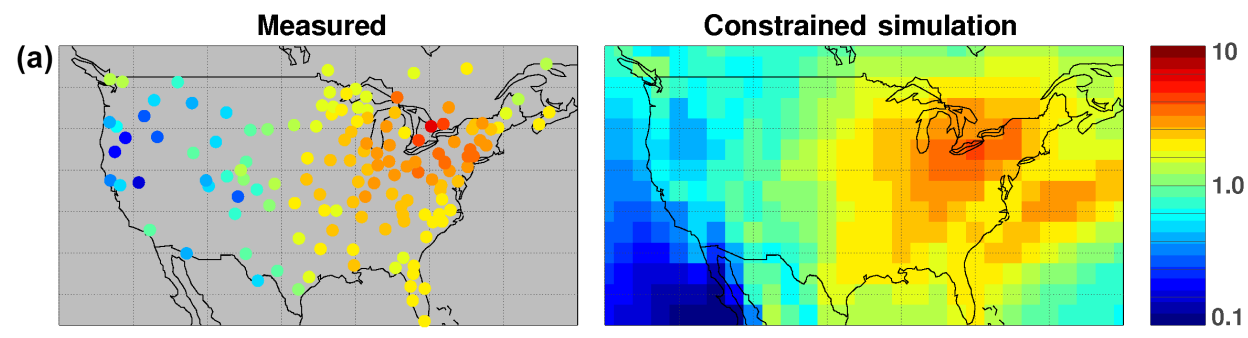

(b)
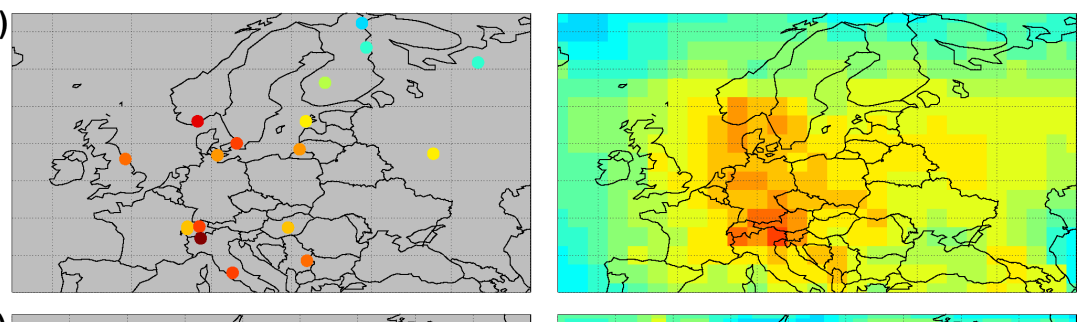

(c)
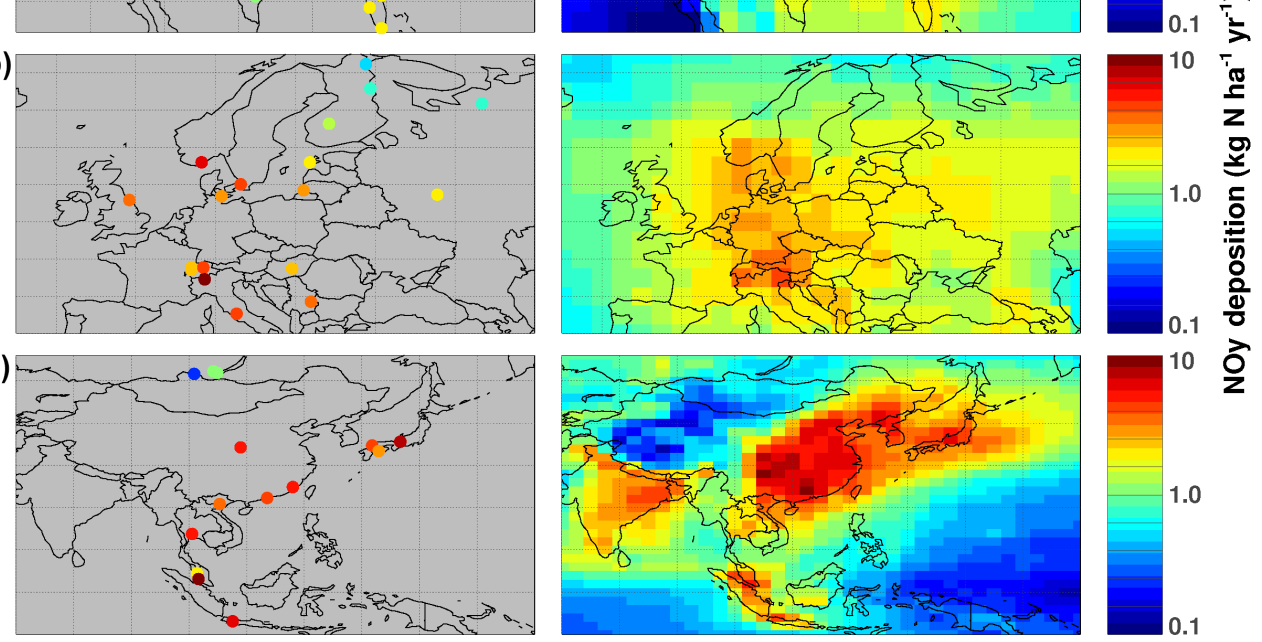

Figure 4. Long-term (1996-2014) wet $\mathrm{NO}_{3}^{-}$deposition from available regional network measurements (a: NADP and CAPMON; b: EMEP; c: EANet) and from the GEOS-Chem simulation, constrained with satellite observations of $\mathrm{NO}_{2}$.

transported farther. The steep change in $\mathrm{NO}_{y}$ deposition in the eastern US over the last 20 years may have important consequences on tree mortality rates in the region, which have been demonstrated to be very sensitive to $\mathrm{NO}_{3}^{-}$deposition in the range of $5-15 \mathrm{~kg} \mathrm{Nha}^{-1} \mathrm{yr}^{-1}$ (Dietze and Moorcroft, 2011). The steeply decreasing trends across the US in our satellite-derived $\mathrm{NO}_{y}$ also support the increasing dominance of reduced nitrogen in total nitrogen deposition, evidenced by observations ( $\mathrm{Li}$ et al., 2016) and model predictions (Ellis et al., 2013).

We find a small but statistically significant positive trend in $\mathrm{NO}_{y}$ deposition $\left(+0.06 \mathrm{~kg} \mathrm{Nha}^{-1} \mathrm{yr}^{-2}\right)$ in northern $\mathrm{Al}-$ berta, Canada, dominated by the trend in JJA. The region is downwind of development in the Canadian oil sands, which has seen notable changes in $\mathrm{NO}_{2}$ column abundance as observed from space (McLinden et al., 2012). We estimate that deposition of $\mathrm{NO}_{y}$ in this area was at a maximum of $3.4 \mathrm{~kg} \mathrm{Nha}^{-1} \mathrm{yr}^{-1}$ in 2011 (up from $1.3 \mathrm{~kg} \mathrm{Nha}^{-1} \mathrm{yr}^{-1}$ in 1996-1997), and has since declined to $1.6 \mathrm{~kg} \mathrm{Nha}^{-1} \mathrm{yr}^{-1}$ by 2014. Elsewhere in Canada we estimate that $\mathrm{NO}_{y}$ deposition has decreased in the southern and eastern parts of the country, consistent with observational analyses (Zbieranowski and Aherne, 2011).

Declines in $\mathrm{NO}_{y}$ deposition are also found across Europe, but statistical significance tends to be limited to western continental Europe and the United Kingdom (while changes in the southern, northern, and eastern countries tend to be insignificant). According to the time series for this region (Fig. 6, middle), $\mathrm{NO}_{y}$ deposition decreased by about $15 \%$ (from $2.5 \mathrm{Tg} \mathrm{N} \mathrm{yr}^{-1}$ in $1996-1998$ to $2.1 \mathrm{Tg} \mathrm{Nyr}^{-1}$ in $\left.2012-2014\right)$. We find the steepest local trends $\left(-0.1 \mathrm{~kg} \mathrm{Nha}^{-2} \mathrm{yr}^{-1}\right)$ in eastern Germany and the southern UK, where $\mathrm{NO}_{y}$ deposition in 2012-2014 decreased by $20 \%$ compared to $1996-1998$. Previous satellite constraints on $\mathrm{NO}_{x}$ emissions established that $\mathrm{NO}_{x}$ emissions in France, Germany, Great Britain, and Poland have declined since 1996 while emissions in Greece, Italy, Spain, and the Ukraine for example have either stayed constant or increased (Konovalov et al., 2008). The local variability in emission trends leads to notable transboundary impacts. For example, our simulation predicts no net trend in $\mathrm{NO}_{y}$ deposition over the Ukraine; but we find this is a result of opposing trends in dry (increasing) and wet (decreasing) deposition. This would be explained by increasing local emissions but decreasing transport from upwind. Similarly, we find significant increases in dry deposition in parts of western Russia but no significant trend in wet deposition.

Large increases in $\mathrm{NO}_{y}$ deposition are found throughout Asia, concentrated especially in eastern China and parts of Southeast Asia. Figure 6 shows the time series of wet and dry $\mathrm{NO}_{y}$ deposition within the rectangular region outlined in Fig. 5 that encompasses eastern China and part of the adjacent ocean. We find that $\mathrm{NO}_{y}$ deposition in the region increased by $65 \%$ from $5.2{\mathrm{Tg} \mathrm{N} \mathrm{yr}^{-1}}^{-1}$ in $1996-1998$ to $8.6 \mathrm{Tg} \mathrm{N} \mathrm{yr}^{-1}$ in $2012-2014$. The time series also shows that $\mathrm{NO}_{y}$ deposition decreased after peak- 

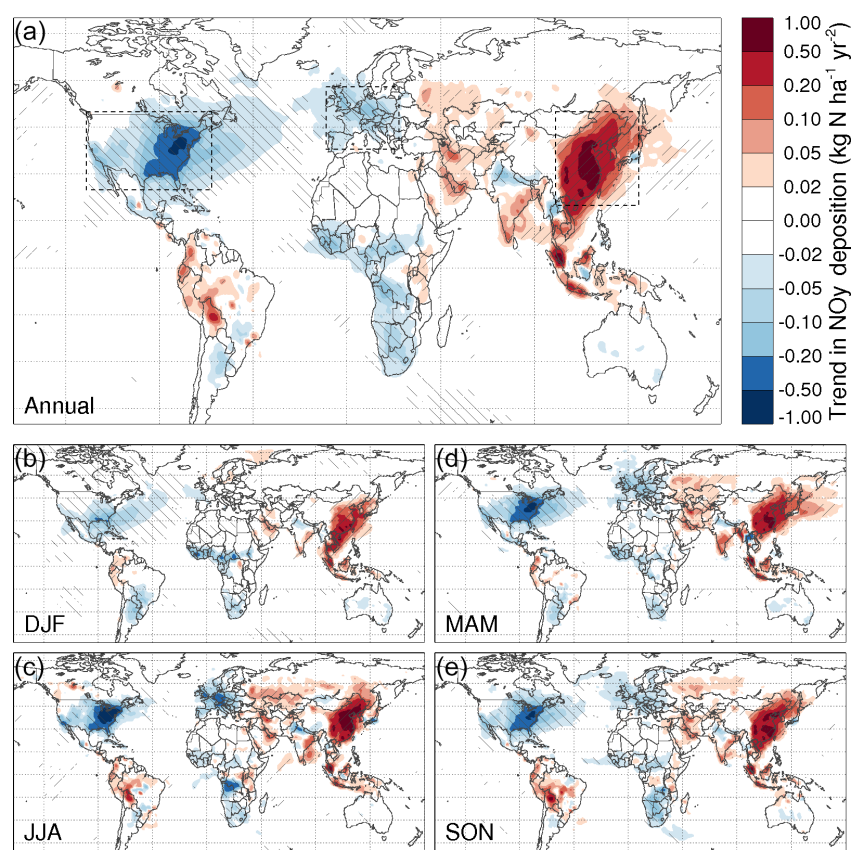

Figure 5. Long-term trend (1996-2014) in the satellite-constrained simulation of $\mathrm{NO}_{y}$ deposition. (a) Annual mean; (b) DecemberJanuary-February; (c) March-April-May; (d) June-July-August; (e) September-October-November. Diagonal hatching represents trend significance $(p<0.01)$. Hatching from top-left to bottom-right indicates a decreasing trend; hatching from bottom-left to top-right indicates an increasing trend.

ing around $9.3 \mathrm{Tg} \mathrm{Nyr}^{-1}$ in 2011-2012. We find that the steepest increasing local trends in the world appear in eastern China, and in the Pearl River Delta region (up to $+0.6 \mathrm{~kg} \mathrm{Nha}^{-1} \mathrm{yr}^{-2}$ ). In fact, deposition in the Pearl River Delta region is the highest in the world for most of our record, exceeding $20 \mathrm{~kg} \mathrm{~N} \mathrm{ha}^{-1} \mathrm{yr}^{-1}$ every year from 2003 to 2014 (almost doubling from just over $11 \mathrm{~kg} \mathrm{~N} \mathrm{ha}^{-1} \mathrm{yr}^{-1}$ in 1996). The trends in deposition over China are largest in summer when the $\mathrm{NO}_{x}$ lifetime is short, with more obvious indications of increasing $\mathrm{NO}_{y}$ transport in the spring months (Fig 5; March-April-May, MAM). The substantial increase in $\mathrm{NO}_{x}$ emissions throughout East Asia has been inferred from satellite instruments in several previous studies (Mijling et al., 2013; Richter et al., 2005). The timing and extent of the reversal in $\mathrm{NO}_{y}$ deposition that we see is also consistent with observed $\mathrm{NO}_{2}$ columns over eastern China derived from OMI (de Foy et al., 2016; Krotkov et al., 2016). The ability of our satellite-constrained $\mathrm{NO}_{y}$ deposition estimate to capture this sudden dramatic decrease over China, in contrast with previous projections (e.g., the RCP2.6, RCP4.5, and RCP8.5 projections to 2030, Lamaque et al., 2013), emphasizes an attribute of the satellite constraint.

Small statistically significant decreasing trends are found over the biomass-burning-dominated source regions of Africa. The decrease in $\mathrm{NO}_{y}$ deposition of about $\sim 3 \% \mathrm{yr}^{-1}$ relative to the long-term mean in northern Africa is consistent with the most recent GFED4 inventory from 1997 to 2014 (http://www.globalfiredata.org/), which has fire $\mathrm{NO}_{x}$ emissions decreasing at a rate of about $3 \% \mathrm{yr}^{-1}$ in this region. In contrast, we also estimate a similar decrease in southern Africa that is not represented in the recent GFED4 emission time series. A reduction in $\mathrm{NO}_{2}$ column abundance in this region (observed by GOME and SCIAMACHY) was also reported by van der A (2008). They postulate that this decline could be a result of deforestation leading to less biomass burning, but changing $\mathrm{NO}_{x}$ emission factors from biomass burning could also potentially contribute to the trend.

Despite the large regional trends described above, we find that global deposition changed very little between 19961998 (56.1 $\mathrm{Tg} \mathrm{N} \mathrm{yr}^{-1}$ ) and 2012-2014 (58.5 $\mathrm{Tg} \mathrm{N} \mathrm{yr}^{-1}$ ) due to the opposing changes in different regions. Total $\mathrm{NO}_{y}$ deposition was lowest in $2006(50.5 \mathrm{Tg} \mathrm{N})$, and peaked at $60.8 \mathrm{Tg} \mathrm{N}$ in 2012. Since then, it appears that global $\mathrm{NO}_{y}$ deposition may be on the decline. Future observations in the coming years will be needed to establish whether this most recent decline is robust or temporary.

Figure 7 shows the calculated long-term trends in the measured wet $\mathrm{NO}_{3}^{-}$deposition for locations across North America, Europe, and East Asia where at least 15 years of qualitycontrolled annual data are available (the coverage of these observation is the same as in Fig. 4). The observations over North America show the gradient in the trend from negligible in the west to steeply and significantly decreasing in the northeastern US and southeastern Canada. The steepest observed statistically significant trend $\left(-0.18 \mathrm{~kg} \mathrm{~N} \mathrm{ha}^{-1} \mathrm{yr}^{-2}\right)$ occurs east of Detroit in southwestern Ontario, Canada. In Europe, only one of the gridded observations has a statistically significant trend $\left(-0.07 \mathrm{~kg} \mathrm{Nha}^{-1} \mathrm{yr}^{-2}\right)$, located near the border of Denmark and Germany. The other locations in Europe show statistically insignificant trends over the longterm. In East Asia, we also we find that most of the stations record statistically negligible trends over the long term (only 2 of the 11 gridded observations have significant trends). The steepest observed trend in this region $\left(+0.39 \mathrm{~kg} \mathrm{~N} \mathrm{ha}^{-1} \mathrm{yr}^{-2}\right)$ is found near Kuala Lumpur and is statistically significant.

We compare the long-term trends in these measurements with our satellite-constrained trends in wet $\mathrm{NO}_{3}^{-}$deposition. We find a similar spatial gradient in North America, and the same magnitude of declines through the northeastern US and southern Ontario ( -0.12 to $\left.-0.16 \mathrm{~kg} \mathrm{~N} \mathrm{ha}^{-1} \mathrm{yr}^{-2}\right)$. Over Europe, our estimates have low statistical significance in the trends throughout much of this region, consistent with the observations. Where we do see statistical significance (the northern United Kingdom, southern Denmark, and in some central to eastern European countries), observations are not available over the long-term for evaluation. In East Asia, our satellite-constrained trend estimates show statistically significant increases throughout much of the region (in contrast to most of the available observations). The trend over Kuala 

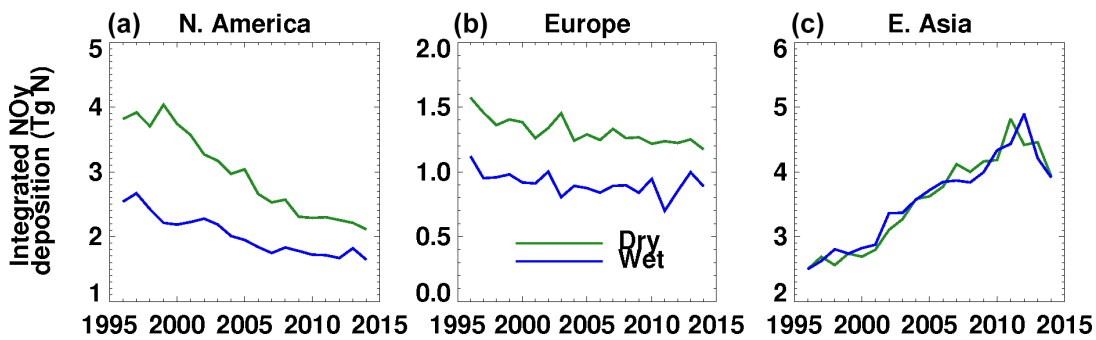

Figure 6. Time series of annually integrated dry and wet $\mathrm{NO}_{y}$ deposition over specific regions (North America, Europe, and East Asia) as defined by the dashed rectangles in Fig. 5 .
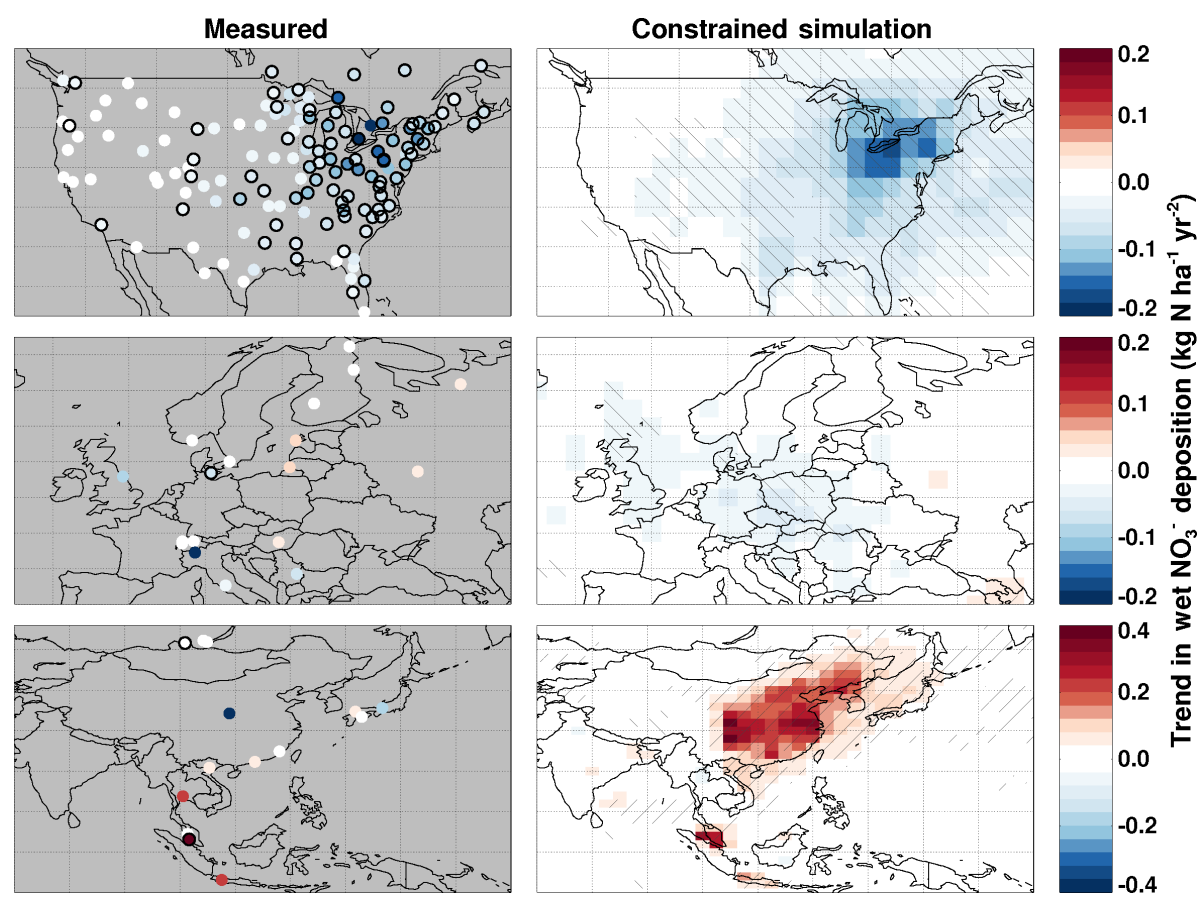

Figure 7. Long-term (1996-2014) trends in wet $\mathrm{NO}_{3}^{-}$deposition from available regional network measurements (as in Fig. 4) and from the GEOS-Chem simulation, constrained by satellite observations of $\mathrm{NO}_{2}$. Closed circles around the measurements indicate significant trends $(p<0.01)$; hatching indicates statistical significance in the simulation.

Lumpur is significant and positive $\left(+0.24 \mathrm{~kg} \mathrm{Nha}^{-1} \mathrm{yr}^{-2}\right)$, as expected from the available measurements.

We again emphasize the small sample size in Europe $(N=16)$ and East Asia $(N=11)$. Moreover, in many cases trends in one (or both) datasets are small and/or insignificant. For these reasons, we focus on comparing the confidence intervals of the measured and satellite-constrained trends. We find that for 129 of the 136 gridded pairs ( $>90 \%$ of the data), the $95 \%$ confidence intervals overlap; of the pairs for which the intervals do not overlap, 3 (out of 109) occur in North America, with 1 (out of 16) in Europe and 3 (out of 11) in East Asia. For a large majority of the data in all three regions we therefore conclude that the satellite-derived trends are not significantly different from the trends inferred with ground-based measurements. Continued long-term measurements with better spatial coverage are imperative to better evaluate long-term estimates of global $\mathrm{NO}_{y}$ deposition, especially throughout Europe and East Asia (but also in other parts of the world where long-term coverage is not available at all).

\subsection{Changes in continental export of $\mathrm{NO}_{y}$}

$\mathrm{NO}_{y}$ deposition is a transboundary, and even intercontinental, issue (HTAP, 2010). In a multimodel study, Sanderson et al. (2008) found that between 3 and $10 \%$ of $\mathrm{NO}_{x}$ emissions from Europe, North America, South Asia, and East Asia are ultimately deposited over foreign regions. Long-range transport events of $\mathrm{NO}_{2}$ alone can be systematically detected by satellite observations (Zien et al., 2014). Here we extend such studies using our satellite-constrained long-term estimates of annual $\mathrm{NO}_{y}$ deposition to evaluate how the amount of $\mathrm{NO}_{x}$ 
exported from specific regions (i.e., the net balance between emissions and deposition over a land area) has changed over the last 2 decades.

Decreases in $\mathrm{NO}_{y}$ export over the Atlantic Ocean from North America and increases in export over the western Pacific Ocean from East Asia are evident in Fig. 5. We find that net export of $\mathrm{NO}_{x}$ from North America via atmospheric transport has decreased by more than $40 \%$ (from 2.5 in 1996, to $1.4 \mathrm{Tg} \mathrm{N} \mathrm{yr}^{-1}$ in 2014). In contrast, we find that export of $\mathrm{NO}_{x}$ from Asia increased by $40 \%$, from $3.3 \mathrm{Tg} \mathrm{N}$ in 1996 to a maximum of $4.7 \mathrm{Tg} \mathrm{N}$ in 2011 , with a subsequent decrease to $3.8 \mathrm{Tg} \mathrm{N}$ by 2014 . As a result of these opposing trends, total deposition to the global oceans has changed remarkably little (25.0 $\mathrm{Tg} \mathrm{N} \mathrm{yr}^{-1}$ in $1996-1998$ compared to $24.4 \mathrm{Tg} \mathrm{N} \mathrm{yr}^{-1}$ in 2012-2014), but has experienced substantial regional redistribution.

$\mathrm{NO}_{y}$ export from North America has received considerable attention. Urban plumes from the eastern US that are transported across the North Atlantic for several days could still contain $20-50 \mathrm{ppb}$ of reactive nitrogen oxides (Neuman et al., 2006). A recent detailed GEOS-Chem study of nitrogen deposition over the US estimated that net annual export of $\mathrm{NO}_{x}$ was around $38 \%$ of $\mathrm{NO}_{x}$ emissions (or $2.5 \mathrm{Tg} \mathrm{N}$ ) for 2006-2008 (Zhang et al., 2012). We estimate a similar fraction of export from the continental US using our observationally constrained simulation (34\% $\pm 2 \%$ from 1996-2014), with a small decreasing trend from $35 \%$ in 1996-1998 to $32 \%$ in 2012-2014. As a result of declining emissions we find that absolute export from the continental US decreased by $50 \%$ from 2.9 in 1996 to $1.5 \mathrm{Tg} \mathrm{N}$ in 2014 . We find declines in $\mathrm{NO}_{y}$ deposition across the Atlantic Ocean, with small though statistically significant declines as far downwind as southern Greenland. The decreases downwind of the continent are clearest and most significant in the winter, spring, and fall (Fig. 5b, c, and e), while the trends are more local in the summer (when the $\mathrm{NO}_{x}$ lifetime is short and when midlatitude wind speeds are weaker).

We similarly calculate the net imbalance between $\mathrm{NO}_{x}$ emissions and $\mathrm{NO}_{y}$ deposition over western European countries and find a decrease of almost $40 \%$, from 2.2 to $1.3 \mathrm{Tg} \mathrm{N}$. We calculate mean export of $\mathrm{NO}_{x}$ emissions from western European countries to be $45 \% \pm 4 \%$, with a notable decreasing trend from $50 \%$ in $1996-1998$ to $40 \%$ in $2012-2014$. As a result, the decrease in net export is steeper than the decrease in emissions from the region. As alluded to in Sect. 3.2, the decrease in $\mathrm{NO}_{x}$ export from some western European countries has likely compensated for increases in emissions in some of the central to eastern European countries, as well as in western Russia, where we find dry deposition has significantly increased, but wet deposition has decreased or shows no significant net trend.

Reactive nitrogen transport from Asia has previously been shown to contribute to $\mathrm{O}_{x}$ production across the midlatitude Pacific, reaching as far as the western coast of North America (Walker et al., 2010; Zhang et al., 2008), and major $\mathrm{NO}_{x}$ transport events from China can be indirectly observed by $\mathrm{NO}_{2}$ columns (Lee et al., 2014). Our satellite-constrained estimate predicts that export from China alone more than tripled from $1.0 \mathrm{TgN}$ in 1996 to a maximum of $3.5 \mathrm{Tg} \mathrm{N}$ in 2011 , then decreased to $2.5 \mathrm{Tg} \mathrm{N}$ by 2014 . We estimate that an average of $24 \% \pm 4 \%$ emissions from China are exported, varying over time from as little as $15 \%$ of emissions in 1998 to a maximum of $31 \%$ of emissions in 2011 (with an overall increasing trend). Zhao et al. (2017) used a higher resolution $\left(0.5^{\circ} \times 0.667^{\circ}\right)$ GEOS-Chem simulation and estimated that $36 \%$ of China's $\mathrm{NO}_{x}$ emissions over 2008-2012 are exported. We calculate an export fraction of around $27 \%$ for the same time period. The discrepancy between the two estimates may be attributed to the coarser horizontal resolution of our simulation $\left(2^{\circ} \times 2.5^{\circ}\right)$, pointing to important resolution-dependent effects in global simulations of deposition. Other factors may include the use of different $\mathrm{NO}_{x}$ emissions (our satellite-constrained emissions indicate rapid change over this period of time), and the treatment of adjacent oceans.

Zhao et al. (2015) used GEOS-Chem to explore nitrogen deposition to the northwestern Pacific Ocean off the coast of China from 2008-2010. They estimated total (wet + dry) $\mathrm{NO}_{y}$ deposition of 6.9 and $3.1 \mathrm{~kg} \mathrm{Nha}^{-1} \mathrm{yr}^{-1}$ to the Yellow Sea and the South China Sea, respectively. Our simulation predicts that $\mathrm{NO}_{y}$ deposition to the same regions of the Yellow Sea increased from 5.1 in 1996 to $9.5 \mathrm{~kg} \mathrm{~N} \mathrm{ha}^{-1} \mathrm{yr}^{-1}$ by 2012 and to the South China Sea from 2.8 in 1996 to $4.3 \mathrm{~kg} \mathrm{Nha}^{-1} \mathrm{yr}^{-1}$ in 2011. Subsequent declines in the following years will hopefully have encouraging implications for nitrogen availability and the incidence of algal blooms in these regions (Hu et al., 2010).

Export of pollution from China has been shown to influence deposition over Japan in particular (e.g., Lin et al., 2008). Using observations of wet nitrate deposition, Morino et al. (2011) report increases throughout Japan from 19892008, and attribute this trend largely to transport from China. Likewise, integrated $\mathrm{NO}_{y}$ deposition over Japan increased $(p<0.01)$ in our satellite-constrained estimate. In fact, we find that Japan transitioned from a net "exporter" of $\mathrm{NO}_{y}$ over 1996-2006 (emissions exceeded local deposition by up to $24 \%$ ) to a net "importer" of $\mathrm{NO}_{y}$ over 2007-2014 (local deposition exceeded emissions by up to $20 \%$ ). The increase in deposition was dominated by statistically significant increases in wet deposition in some parts of the country. We find the increase over Japan is most uniform during the spring (Fig. 5, MAM), consistent with transport from China being pronounced during the spring season (Tanimoto et al., 2005). Nevertheless, the impacts of local $\mathrm{NO}_{x}$ controls can also be important. Dry deposition dominates the decline in annual $\mathrm{NO}_{y}$ deposition just west of Tokyo. Declines are seen throughout the southern part of the country during both the summer and fall seasons (Fig. 5, JJA and SON, September, October, and November). These results demonstrate the indirect relationship between local emissions and local deposi- 
tion of $\mathrm{NO}_{y}$ for regions influenced by atmospheric transport and also show how long-term trends can depend strongly on the season and process (wet or dry deposition).

\subsection{Sensitivity of $\mathrm{NO}_{y}$ deposition to $\mathrm{NH}_{3}$ emissions}

The transport and ultimate deposition of oxidized nitrogen may be tightly coupled with the reduced nitrogen $\left(\mathrm{NH}_{x}=\mathrm{NH}_{3}+\mathrm{NH}_{4}^{+}\right)$and sulfate systems, due to the formation of $\mathrm{NH}_{4} \mathrm{NO}_{3}$ aerosol that becomes favorable once all $\mathrm{H}_{2} \mathrm{SO}_{4}$ has been neutralized (i.e., if there is "excess" $\mathrm{NH}_{3}$ ). Examples of the resulting nonlinearity between $\mathrm{PM}_{2.5}$ concentrations and precursor emissions have been noted in the literature (Banzhaf et al., 2013; Derwent et al., 2009; Fowler et al., 2005). The formation of $\mathrm{NH}_{4} \mathrm{NO}_{3}$ aerosol at the expense of $\mathrm{HNO}_{3}$ with changing excess ammonia could therefore conceivably change the atmospheric lifetime of $\mathrm{NO}_{y}$ at the surface; accumulation-mode aerosol may have a dry deposition lifetime of days, whereas $\mathrm{HNO}_{3}$ tends to have a dry deposition lifetime of shorter than a day. As a result, the predicted footprint of source impacts is sensitive to $\mathrm{NH}_{3}$ emissions (Lee et al., 2016).

Contemporary emissions of $\mathrm{NH}_{3}$ are highly uncertain (Reis et al., 2009), so we perform a sensitivity experiment by perturbing (increasing) all anthropogenic and natural $\mathrm{NH}_{3}$ emissions in the model by $25 \%$ for the year 2012. Predicted $\mathrm{NO}_{y}$ deposition from this simulation is compared to the predicted $\mathrm{NO}_{y}$ deposition in the 2012 simulation where $\mathrm{NH}_{3}$ emissions were not perturbed. Since we have not altered the emissions of oxidized nitrogen, simple mass balance dictates that increases in deposition over some regions will be countered by decreases elsewhere. Our perturbation is therefore to be interpreted as an experiment that tests how accurately the spatial pattern in $\mathrm{NO}_{y}$ deposition at our model resolution can be predicted, given some uncertainty in $\mathrm{NH}_{3}$ emissions. Given the horizontal resolution of our simulation $\left(2.5^{\circ} \times 2.0^{\circ}\right)$, we acknowledge that our estimates of the sensitivity of $\mathrm{NO}_{y}$ deposition to perturbations in $\mathrm{NH}_{3}$ emissions may underestimate the importance of those interactions on finer spatial scales.

Figure 8 shows the results of this experiment. The sensitivity of $\mathrm{NO}_{y}$ deposition to an increase in $\mathrm{NH}_{3}$ emissions is positive or negative depending on the region, while net deposition over the global domain does not change (to within 1$2 \%)$. Over the continents, the sensitivity in total (wet + dry) $\mathrm{NO}_{y}$ deposition to the $25 \%$ perturbation in $\mathrm{NH}_{3}$ emissions tends to be less than $\pm 5 \%$, with a few exceptions. We find differences in $\mathrm{NO}_{y}$ deposition on the order of $10 \%$ over parts of high-latitude Russia, northwest and central Africa, eastern China, southern South America, and Australia. However, with the exception of China, these are also regions where deposition is relatively low. We conclude that for most regions of interest, our satellite-constrained estimates of $\mathrm{NO}_{y}$ deposition over the continents and their trends will not be severely impacted by uncertainty in the $\mathrm{NH}_{3}$ inventories.
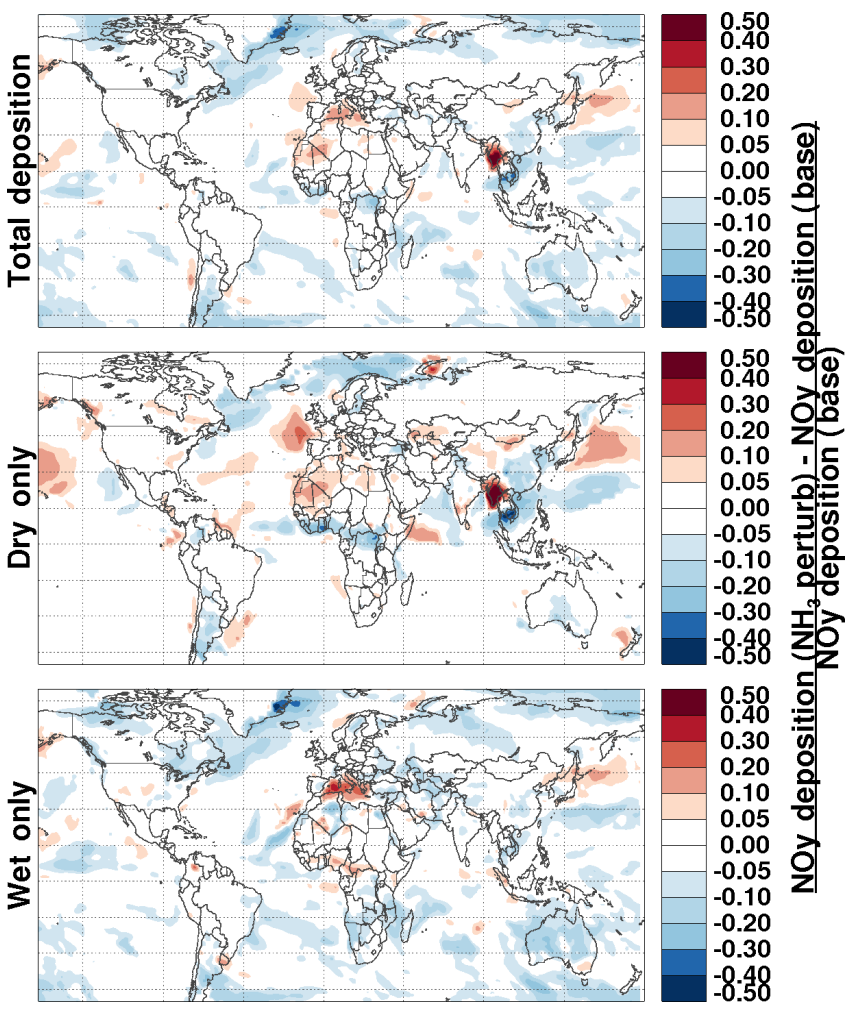

Figure 8. Sensitivity of simulated $\mathrm{NO}_{y}$ deposition in 2012 to a $25 \%$ perturbation (increase) in ammonia emissions in all grid boxes (shown separately for total deposition, dry deposition, and wet deposition).

Notably, the difference exceeds $+50 \%$ over Myanmar, suggesting that simulated $\mathrm{NO}_{y}$ deposition over this country is extremely sensitive to changes in $\mathrm{NH}_{3}$ emissions. It is clear from Fig. 8 that this results from a high sensitivity in dry deposition (middle panel) instead of wet deposition (bottom panel). Myanmar has some of the lowest estimated $\mathrm{NH}_{3}$ emissions in all of South and East Asia (at least an order of magnitude lower than surrounding India, China, and Thailand), so this sensitivity reflects changes in the upwind emissions and subsequent transport of $\mathrm{NO}_{y}$. We find the opposite sensitivity in nearby Cambodia, where the sensitivity of dry $\mathrm{NO}_{y}$ deposition to a $25 \%$ perturbation is $\mathrm{NH}_{3}$ emissions is $-50 \%$.

Over the oceans, the sensitivity of $\mathrm{NO}_{y}$ deposition to the $25 \%$ increase in $\mathrm{NH}_{3}$ emissions is generally low $(< \pm 5 \%)$, with the expected exceptions in areas that are directly offshore from major continental source regions. In the North Atlantic Ocean east of Canada and Greenland, the North Pacific Ocean off the coasts of China, Japan, and the South China Sea, the sensitivity of $\mathrm{NO}_{y}$ deposition is between 5 and $20 \%$. Our predicted decrease in dry $\mathrm{NO}_{y}$ deposition to the Yellow Sea given an increase in $\mathrm{NH}_{3}$ emissions is consistent with previous adjoint analyses showing increased $\mathrm{NO}_{y}$ dry deposition in this region with a decrease in Asian $\mathrm{NH}_{3}$ 
emissions (Zhao et al., 2015). Likewise, the sensitivity of deposition to the Mediterranean Sea is between 10 and $20 \%$. The differences in $\mathrm{NO}_{y}$ deposition over the oceans results from sensitivity in both dry and wet deposition (although in the case of the Mediterranean it is dominated by dry deposition). We conclude that although changes (or uncertainties) in $\mathrm{NH}_{3}$ emissions can impact the distance of transport and deposition to oceans downwind of the major $\mathrm{NO}_{x}$ sources, the absolute magnitude of deposition is low where the sensitivity of $\mathrm{NO}_{y}$ deposition to $\mathrm{NH}_{3}$ is relatively high.

\subsection{Other considerations}

A number of other uncertainties are important in an inversion of satellite $\mathrm{NO}_{2}$ columns to calculate surface $\mathrm{NO}_{x}$ emissions and simulate long-term $\mathrm{NO}_{y}$ deposition. These can depend on, for example, the choice of inversion approach, errors in the satellite retrieval, and uncertainties in model processes (e.g., emissions, boundary layer mixing, chemical $\mathrm{NO}_{x}$ sinks, meteorology, and dry deposition).

Cooper et al. (2017) found that the finite mass-balance inversion approach used here can be improved upon by using an iterative method that performs with similar accuracy as a four-dimensional variational data assimilation. Multiconstituent data assimilation also shows considerable promise for constraints on surface $\mathrm{NO}_{x}$ emissions (Myazaki et al., 2017). Satellite retrieval algorithms continue to develop with advances that will improve the accuracy of future estimates of satellite-constrained $\mathrm{NO}_{y}$ deposition.

Uncertainties in model processes are also of interest. For example, uncertainties in the chemical sink of $\mathrm{NO}_{x}$ alone (e.g., the rate of $\mathrm{HNO}_{3}$ formation, heterogeneous loss of $\mathrm{N}_{2} \mathrm{O}_{5}$ onto aerosol) can have a substantial impact on topdown emissions estimates (Stavrakou et al., 2013), suggesting more fundamental work in constraining these processes is required. Lin et al. (2010) found that top-down $\mathrm{NO}_{x}$ emissions estimates over East Asia are sensitive to other model uncertainties, including planetary boundary layer mixing scheme, lightning emissions, diurnal profile of emissions, and a priori $\mathrm{NO}_{x}, \mathrm{CO}$, and VOC emissions. Uncertainties in model meteorology are also important. For example, the MERRA precipitation fields used in our study are known to correlate weakly with observational datasets (Rienecker et al., 2011), but improvements can be expected from MERRA2 due to the inclusion of gauge- and satellite-based precipitation corrections (Reichle et al., 2017). Finally, dry deposition schemes are also highly variable among models (Flechard et al., 2011; Hardacre et al., 2015), and future work in dry deposition evaluation should be a priority.

Nonetheless, despite these uncertainties we find a high degree of consistency between observations and our predictions in the long-term changes to deposition. Evidence continues to emerge about potential biases in bottom-up inventories (e.g., Travis et al., 2016), and our observational constraint on $\mathrm{NO}_{x}$ emissions mitigates against such biases. We expect that continued advancements in inversion approaches, satellite retrieval algorithms, and fundamental atmospheric chemistry processes will allow for increasingly accurate satellite-based constraints on deposition.

\section{Conclusions}

$\mathrm{NO}_{y}$ deposition represents about half of the total reactive nitrogen deposited to Earth's surface. Even in the US where nitrogen oxide emissions have decreased substantially, constituents of $\mathrm{NO}_{y}$ remain major contributors to the nitrogen deposited in areas of concern (Lee et al., 2016; Li et al., 2016). We applied $\mathrm{NO}_{2}$ observations from multiple satellites over 1996-2014 together with the GEOS-Chem chemical transport model to estimate long-term changes to reactive nitrogen oxide deposition around the world. Given the effective global mass balance between $\mathrm{NO}_{x}$ emissions and deposition of reactive nitrogen oxides, we show that satellite constraints on $\mathrm{NO}_{x}$ emissions can provide a powerful topdown constraint on deposition in order to evaluate long-term changes worldwide. Observations from the GOME, SCIAMACHY, and GOME-2 satellite instruments have provided continuous global coverage over the last 20 years, allowing observational constraints on $\mathrm{NO}_{y}$ deposition that enhance the poor spatial coverage of ground-based deposition measurements.

We find substantial variability in regional trends of $\mathrm{NO}_{y}$ deposition. $\mathrm{NO}_{y}$ deposition declined most steeply throughout the northeastern United States at a rate of up to $-0.6 \mathrm{~kg} \mathrm{Nha}^{-1} \mathrm{yr}^{-2}$, but has also decreased significantly throughout most of the country and in southern Canada. In Europe, statistically significant declines at a rate of up to $-0.1 \mathrm{~kg} \mathrm{Nha}^{-1} \mathrm{yr}^{-2}$ are seen over some western countries. $\mathrm{NO}_{y}$ deposition has increased substantially throughout East Asia, exceeding a rate of $+0.6 \mathrm{~kg} \mathrm{Nha}^{-1} \mathrm{yr}^{-2}$ in some parts. Since reductions in deposition over some regions were counteracted by increases in others, global $\mathrm{NO}_{y}$ deposition did not change considerably over the long term. However, we find that global $\mathrm{NO}_{y}$ deposition could now be on the decline overall, since deposition in Asia peaked around 2010-2012. The ability to resolve the striking recent decline in $\mathrm{NO}_{y}$ deposition in China (despite prior projections of increasing $\mathrm{NO}_{x}$ emissions) demonstrates one of the attributes of using a satellite-based constraint. Future observations will be important in evaluating whether this trend persists.

We find that changes over the last 2 decades in the export of reactive nitrogen oxides via atmospheric transport have impacted countries downwind of source regions. Export from North America has decreased by at least $40 \%$, while export from Asia has increased by the same relative amount. We find evidence that decreases in $\mathrm{NO}_{x}$ export from some western European countries have counteracted increases in local emissions from some eastern and central European countries, resulting in negligible net change in $\mathrm{NO}_{y}$ deposition over 
the long term. Likewise, Japan is highly sensitive to changes in export from China, but this depends strongly on the season and whether wet and dry deposition are both considered. While uncertainty in $\mathrm{NH}_{3}$ emissions can impact the footprint of $\mathrm{NO}_{y}$ export and deposition, we show that this sensitivity is small in most regions of concern.

Direct measurements of deposition are sparse, inhibiting evaluation. This is especially challenging for global simulations, where individual measurements may not necessarily be regionally representative. Nevertheless, we find that for the vast majority of locations our satellite-derived trends are largely consistent with the observed trends. Expanded coverage of ground-based observations over the long-term is needed to more comprehensively evaluate long-term estimates of global $\mathrm{NO}_{y}$ deposition. This need also motivates the value of using alternative observational constraints such as the satellite $\mathrm{NO}_{2}$ columns, as presented here.

Forthcoming satellite observations of $\mathrm{NO}_{2}$ at higher spatial resolution (e.g., TROPOMI; Veefkind et al., 2012) and with diurnally varying observations (e.g., TEMPO; Zoogman et al., 2017, Sentinel-4, and GEMS) will offer increasingly robust constraints on $\mathrm{NO}_{x}$ emissions that affect $\mathrm{NO}_{y}$ deposition. Satellite observations of $\mathrm{NH}_{3}$ (e.g., Van Damme et al., 2014) may offer additional opportunities to constrain the reactive nitrogen budget. Higher resolution global modeling will also be an important development to accurately account for nonlinear $\mathrm{NO}_{2}$ losses in global emission inversions (Valin et al., 2011).

Our satellite-constrained estimates of $\mathrm{NO}_{y}$ document interannual changes over the past 2 decades worldwide. We expect that this information will be useful in future research into the impacts of nitrogen deposition to important biodiversity hotspots, in regions dealing with excessive nitrogen inputs leading to algal blooms, or for estimating the changing impacts of nitrogen deposition on global carbon uptake.
Data availability. Wet $\mathrm{NO}_{3}^{-}$deposition data from the World Data Centre for Precipitation Chemistry for 2000-2002 and for 20052007 can be accessed at http://www.wdcpc.org/assessment. Wet $\mathrm{NO}_{3}^{-}$deposition data from the National Atmospheric Deposition Program in the United States can be accessed at http: //nadp.sws.uiuc.edu/data/. Wet $\mathrm{NO}_{3}^{-}$deposition data from the Canadian Air Precipitation Monitoring Network in Canada can be accessed at http://www.ec.gc.ca/rs-mn/default.asp?lang=En\&n= 6C8C66C5-1. Wet $\mathrm{NO}_{3}^{-}$deposition data from the Acid Deposition Monitoring Network in East Asia can be accessed at http: //www.eanet.asia/product/index.html. Satellite-derived NO2 tropospheric column density observations from GOME, SCIAMACHY, and GOME-2 can be accessed at http://www.temis.nl/airpollution/ no2.html. Our gridded satellite-derived estimates of global annual $\mathrm{NO}_{y}$ deposition can be downloaded from http://fizz.phys.dal.ca/ $\sim$ atmos/martin/?page_id $=1520$, or obtained by contacting the principal investigator, Jeffrey Geddes (jgeddes@bu.edu). 


\section{Appendix A}

We simulate atmospheric chemistry from 1996 to 2014 using the GEOS-Chem chemical transport model (www. geos-chem.org) v9-02. Our simulations are driven with the MERRA meteorological product at a global horizontal resolution of $2.5^{\circ} \times 2.0^{\circ}$ and 47 vertical layers. GEOS-Chem includes detailed $\mathrm{HO}_{x}-\mathrm{NO}_{x}-\mathrm{VOC}-\mathrm{O}_{3}$-aerosol chemistry (Bey et al., 2001; Park et al., 2004), with isoprene chemistry following Paulot et al. (2009a, b) and gas-aerosol partitioning for the sulfate-nitrate-ammonium system calculated according to the ISORROPIA II equilibrium model (Fountoukis and Nenes, 2007). Gas-aerosol phase coupling occurs via $\mathrm{N}_{2} \mathrm{O}_{5}$ uptake (Evans and Jacob, 2005) and $\mathrm{HO}_{2}$ uptake (Mao et al., 2013) in addition to other heterogeneous chemistry (Jacob, 2000) and aerosol effects on photolysis frequencies (Martin et al., 2003). Our simulations use time steps of $15 \mathrm{~min}$ for transport and convection, and $30 \mathrm{~min}$ for emissions and chemistry.

Removal by wet deposition occurs through scavenging in moist convective updrafts, as well as in-cloud and belowcloud scavenging during large-scale precipitation for watersoluble aerosol and gases (Amos et al., 2012; Liu et al., 2001). Removal by dry deposition is calculated based on the widely used resistance-in-series formulation from Wesely (1989), described for GEOS-Chem in Wang et al. (1998) and Zhang et al. (2001) for aerosol. Dry deposition of $\mathrm{NO}_{y}$ over the United States was recently explored and evaluated in detail by Zhang et al. (2012).

Anthropogenic emissions are prescribed by the NEI 2005 inventory for the United States (http: //www.epa.gov/ttnchie1/trends/), the CAC inventory for Canada (www.ec.gc.ca/indicateurs-indicators/default.asp? lang=en\&n=E79F4C12-1), the BRAVO inventory for Mexico (Kuhns et al., 2005), the EMEP inventory for Europe (http://www.emep.int/), and Zhang et al. (2009) for China and Southeast Asia. Elsewhere, the EDGAR v3 emission inventory is used for anthropogenic $\mathrm{NO}_{x}, \mathrm{CO}$, and $\mathrm{SO}_{x}$ (Olivier et al., 2005); the GEIA inventory for $\mathrm{NH}_{3}$ (Bouwman et al., 1997); and the RETRO inventory for VOCs (Hu et al., 2015). Monthly scaling of $\mathrm{NO}_{x}$ emissions is included in North America (based on the VISTAS inventory), Europe (based on the EMEP inventory), and Asia (based on the Zhang et al., 2009 inventory). Monthly scaling of EDGAR emissions is based on the seasonality from the Global Emission Inventory Activity (Benkovitz et al., 1996). Aircraft emissions are from the AEIC inventory (Stettler et al., 2011). Scale factors based on energy statistics following van Donkelaar et al. (2008) are used to scale $\mathrm{NO}_{x}, \mathrm{CO}$, and $\mathrm{SO}_{x}$ emissions between 1996 and 2010 for years when the emissions are unavailable from the inventory. For other species and for emissions beyond 2010, the closest available year is used. Biogenic VOC emissions are calculated using the MEGAN model (Guenther et al., 2006). Biomass burning emissions are according to the GFED3 inventory (Mu et al.,
2011). Soil $\mathrm{NO}_{x}$ is calculated using the Berkeley-Dalhousie parameterization (Hudman et al., 2012). Lightning $\mathrm{NO}_{x}$ is implemented according to Murray et al. (2012). These a priori surface $\mathrm{NO}_{x}$ emissions are overwritten by our satellite-derived top-down estimates in the assessment of $\mathrm{NO}_{y}$ deposition. 
Competing interests. The authors declare that they have no conflict of interest.

Acknowledgements. This work was supported by NSERC and Environment and Climate Change Canada. We acknowledge the free use of tropospheric $\mathrm{NO}_{2}$ column data from the GOME, SCIAMACHY, and GOME-2 sensors from www.temis.nl. We further acknowledge the NADP, CAPMoN, EMEP, and EANET regional monitoring networks as well as the World Data Centre for Precipitation Chemistry for access to wet deposition data.

Edited by: Michel Van Roozendael

Reviewed by: three anonymous referees

\section{References}

Amos, H. M., Jacob, D. J., Holmes, C. D., Fisher, J. A., Wang, Q., Yantosca, R. M., Corbitt, E. S., Galarneau, E., Rutter, A. P., Gustin, M. S., Steffen, A., Schauer, J. J., Graydon, J. A., Louis, V. L. St., Talbot, R. W., Edgerton, E. S., Zhang, Y., and Sunderland, E. M.: Gas-particle partitioning of atmospheric $\mathrm{Hg}$ (II) and its effect on global mercury deposition, Atmos. Chem. Phys., 12, 591-603, https://doi.org/10.5194/acp-12-591-2012, 2012.

Banzhaf, S., Schaap, M., Wichink Kruit, R. J., Denier van der Gon, H. A. C., Stern, R., and Builtjes, P. J. H.: Impact of emission changes on secondary inorganic aerosol episodes across Germany, Atmos. Chem. Phys., 13, 1167511693, https://doi.org/10.5194/acp-13-11675-2013, 2013.

Beirle, S., Huntrieser, H., and Wagner, T.: Direct satellite observation of lightning-produced $\mathrm{NO}_{x}$, Atmos. Chem. Phys., 10, 10965-10986, https://doi.org/10.5194/acp-10-10965-2010, 2010.

Benkovitz, C. M., Scholtz, M. T., Pacyna, J., Tarrason, L., Dignon, J., Voldner, E. C., Spiro, P. A., Logan, J. A., and Graedel, T. E.: Global gridded inventories of anthropogenic emissions of sulfur and nitrogen, J. Geophys. Res., 101, 29239-29253, 1996.

Bey, I., Jacob, D. J., Yantosca, R. M., Logan, J. A., Field, B. D., Fiore, A. M., Li, Q., Liu, H. Y., Mickley, L. J., and Schultz, M. G.: Global modeling of tropospheric chemistry with assimilated meteorology: Model description and evaluation, J. Geophys. Res., 106, 23073, https://doi.org/10.1029/2001JD000807, 2001.

Bobbink, R., Hicks, K., Galloway, J., Spranger, T., Alkemade, R., Ashmore, M., Bustamante, M., Cinderby, S., Davidson, E., Dentener, F., Emmett, B., Erisman, J.-W., Fenn, M., Gilliam, F., Nordin, A., Pardo, L., and De Vries, W.: Global assessment of nitrogen deposition effects on terrestrial plant diversity: a synthesis, Ecol. Appl., 20, 30-59, https://doi.org/10.1890/08-1140.1, 2010.

Boersma, K. F., Eskes, H. J., and Brinksma, E. J.: Error analysis for tropospheric NO2 retrieval from space, J. Geophys. Res., 109, D04311, https://doi.org/10.1029/2003JD003962, 2004.

Boersma, K. F., Vinken, G. C. M., and Eskes, H. J.: Representativeness errors in comparing chemistry transport and chemistry climate models with satellite UV-Vis tropospheric column retrievals, Geosci. Model Dev., 9, 875-898, https://doi.org/10.5194/gmd-9-875-2016, 2016.
Bouwman, A. F., Lee, D. S., Asman, W. A. H., Dentener, F. J., Van Der Hoek, K. W., and Olivier, J. G. J.: A global high-resolution emission inventory for ammonia, Global Biogeochem. Cy., 11, 561-587, https://doi.org/10.1029/97GB02266, 1997.

Bouwman, A. F., Van Vuuren, D. P., Derwent, R. G., and Posch, M.: A Global Analysis of Acidification and Eutrophication of Terrestrial Ecosystems, Water. Air. Soil Pollut., 141, 349-382, https://doi.org/10.1023/A:1021398008726, 2002.

Castellanos, P. and Boersma, K. F.: Reductions in nitrogen oxides over Europe driven by environmental policy and economic recession, Sci. Rep., 2, 35912, https://doi.org/10.1038/srep00265, 2012.

Cheng, M., Jiang, H., Guo, Z., Zhang, X., and Lu, X.: Estimating $\mathrm{NO}_{2}$ dry deposition using satellite data in eastern China, Int. J. Remote Sens., 34, 2548-2565, https://doi.org/10.1080/01431161.2012.747019, 2013.

Cooper, M., Martin, R. V., Padmanabhan, A., and Henze, D. K.: Comparing mass balance and adjoint methods for inverse modeling of nitrogen dioxide columns for global nitrogen oxide emissions, J. Geophys. Res.-Atmos., 122, 4718-4734, https://doi.org/10.1002/2016JD025985, 2017.

de Foy, B., Lu, Z., and Streets, D. G.: Satellite NO2 retrievals suggest China has exceeded its $\mathrm{NO}_{x}$ reduction goals from the twelfth Five-Year Plan, Sci. Rep., 6, 35912, https://doi.org/10.1038/srep35912, 2016.

Dentener, F., Drevet, J., Lamarque, J. F., Bey, I., Eickhout, B., Fiore, A. M., Hauglustaine, D., Horowitz, L. W., Krol, M., Kulshrestha, U. C., Lawrence, M., Galy-Lacaux, C., Rast, S., Shindell, D., Stevenson, D., Van Noije, T., Atherton, C., Bell, N., Bergman, D., Butler, T., Cofala, J., Collins, B., Doherty, R., Ellingsen, K., Galloway, J., Gauss, M., Montanaro, V., Müller, J. F., Pitari, G., Rodriguez, J., Sanderson, M., Solmon, F., Strahan, S., Schultz, M., Sudo, K., Szopa, S., and Wild, O.: Nitrogen and sulfur deposition on regional and global scales: A multimodel evaluation, Global Biogeochem. Cy., 20, GB4003, https://doi.org/10.1029/2005GB002672, 2006.

Derwent, R., Witham, C., Redington, A., Jenkin, M., Stedman, J., Yardley, R., and Hayman, G.: Particulate matter at a rural location in southern England during 2006: Model sensitivities to precursor emissions, Atmos. Environ., 43, 689-696, https://doi.org/10.1016/j.atmosenv.2008.09.077, 2009.

De Schrijver, A., De Frenne, P., Ampoorter, E., Van Nevel, L., Demey, A., Wuyts, K., and Verheyen, K.: Cumulative nitrogen input drives species loss in terrestrial ecosystems, Global Ecol. Biogeogr., 20, 803-816, https://doi.org/10.1111/j.14668238.2011.00652.x, 2011.

Dietze, M. C. and Moorcroft, P. R.: Tree mortality in the eastern and central United States: patterns and drivers, Glob. Change Biol., 17, 3312-3326, https://doi.org/10.1111/j.13652486.2011.02477.x, 2011.

Duce, R. A., LaRoche, J., Altieri, K., Arrigo, K. R., Baker, A. R., Capone, D. G., Cornell, S., Dentener, F., Galloway, J., Ganeshram, R. S., Geider, R. J., Jickells, T., Kuypers, M. M., Langlois, R., Liss, P. S., Liu, S. M., Middelburg, J. J., Moore, C. M., Nickovic, S., Oschlies, A., Pedersen, T., Prospero, J., Schlitzer, R., Seitzinger, S., Sorensen, L. L., Uematsu, M., Ulloa, O., Voss, M., Ward, B., and Zamora, L.: Impacts of atmospheric anthropogenic nitrogen on the open ocean, Science, 320, 893-897, https://doi.org/10.1126/science.1150369, 2008. 
Duncan, B. N., Yoshida, Y., de Foy, B., Lamsal, L. N., Streets, D. G., Lu, Z., Pickering, K. E., and Krotkov, N. A.: The observed response of Ozone Monitoring Instrument (OMI) $\mathrm{NO}_{2}$ columns to NOx emission controls on power plants in the United States: 2005-2011, Atmos. Environ., 81, 102-111, https://doi.org/10.1016/j.atmosenv.2013.08.068, 2013.

Ellis, R. A., Jacob, D. J., Sulprizio, M. P., Zhang, L., Holmes, C. D., Schichtel, B. A., Blett, T., Porter, E., Pardo, L. H., and Lynch, J. A.: Present and future nitrogen deposition to national parks in the United States: critical load exceedances, Atmos. Chem. Phys., 13, 9083-9095, https://doi.org/10.5194/acp13-9083-2013, 2013.

Evans, M. J. and Jacob, D. J.: Impact of new laboratory studies of $\mathrm{N}_{2} \mathrm{O}_{5}$ hydrolysis on global model budgets of tropospheric nitrogen oxides, ozone, and OH, Geophys. Res. Lett., 32, L09813, https://doi.org/10.1029/2005GL022469, 2005.

Flechard, C. R., Nemitz, E., Smith, R. I., Fowler, D., Vermeulen, A. T., Bleeker, A., Erisman, J. W., Simpson, D., Zhang, L., Tang, Y. S., and Sutton, M. A.: Dry deposition of reactive nitrogen to European ecosystems: a comparison of inferential models across the NitroEurope network, Atmos. Chem. Phys., 11, 2703-2728, https://doi.org/10.5194/acp-11-2703-2011, 2011.

Fountoukis, C. and Nenes, A.: ISORROPIA II: a computationally efficient thermodynamic equilibrium model for $\mathrm{K}^{+}-\mathrm{Ca}^{2+}$. $\mathrm{Mg}^{2+}-\mathrm{NH}_{4}^{+}-\mathrm{Na}^{+}-\mathrm{SO}_{4}^{2}-\mathrm{NO}_{3}-\mathrm{Cl}-\mathrm{H}_{2} \mathrm{O}$ aerosols, Atmos. Chem. Phys., 7, 4639-4659, https://doi.org/10.5194/acp-7-4639-2007, 2007.

Fowler, D., Muller, J., Smith, R. I., Cape, J. N., and Erisman, J. W.: Nonlinearities in source receptor relationships for sulfur and nitrogen compounds, Ambio, 34, 41-46, 2005.

Galloway, J. N., Dentener, F. J., Capone, D. G., Boyer, E. W., Howarth, R. W., Seitzinger, S. P., Asner, G. P., Cleveland, C. C., Green, P. A., Holland, E. A., Karl, D. M., Michaels, A. F., Porter, J. H., Townsend, A. R., and Vorosmarty, C. J.: Nitrogen cycles: past, present, and future, Biogeochemistry, 70, 153-226, 2004.

Galloway, J. N., Townsend, A. R., Erisman, J. W., Bekunda, M., Cai, Z., Freney, J. R., Martinelli, L. A., Seitzinger, S. P., and Sutton, M. A.: Transformation of the Nitrogen Cycle: Recent Trends, Questions, and Potential Solutions, Science, 320, 889892, https://doi.org/10.1126/science.1136674, 2008.

Geddes, J. A., Martin, R. V., Boys, B. L., and van Donkelaar, A.: Long-Term Trends Worldwide in Ambient $\mathrm{NO}_{2}$ Concentrations Inferred from Satellite Observations, Environ. Health Persp., 124, 281-289, https://doi.org/10.1289/ehp.1409567, 2015.

Guenther, A., Karl, T., Harley, P., Wiedinmyer, C., Palmer, P. I., and Geron, C.: Estimates of global terrestrial isoprene emissions using MEGAN (Model of Emissions of Gases and Aerosols from Nature), Atmos. Chem. Phys., 6, 3181-3210, https://doi.org/10.5194/acp-6-3181-2006, 2006.

Hardacre, C., Wild, O., and Emberson, L.: An evaluation of ozone dry deposition in global scale chemistry climate models, Atmos. Chem. Phys., 15, 6419-6436, https://doi.org/10.5194/acp15-6419-2015, 2015.

Hernández, D. L., Vallano, D. M., Zavaleta, E. S., Tzankova, Z., Pasari, J. R., Weiss, S., Selmants, P. C., and Morozumi, C.: Nitrogen Pollution Is Linked to US Listed Species Declines, Bioscience, 66, 213-222, https://doi.org/10.1093/biosci/biw003, 2016.
Hilboll, A., Richter, A., and Burrows, J. P.: Long-term changes of tropospheric $\mathrm{NO}_{2}$ over megacities derived from multiple satellite instruments, Atmos. Chem. Phys., 13, 4145-4169, https://doi.org/10.5194/acp-13-4145-2013, 2013.

Holland, E. A., Braswell, B. H., Sulzman, J., and Lamarque, J. F.: Nitrogen deposition onto the United States and western Europe: Synthesis of observations and models, Ecol. Appl., 15, 38-57, https://doi.org/10.1890/03-5162, 2005.

HTAP: Hemispheric Transport of Air Pollution 2010 - Part A: Ozone and Particulate Matter, New York, available at: http:// www.htap.org/ (last access: 16 August 2017), 2010.

Hu, C., Li, D., Chen, C., Ge, J., Muller-Karger, F. E., Liu, J., Yu, F., and He, M.-X.: On the recurrent Ulva prolifera blooms in the Yellow Sea and East China Sea, J. Geophys. Res., 115, C05017, https://doi.org/10.1029/2009JC005561, 2010.

Hu, L., Millet, D. B., Baasandorj, M., Griffis, T. J., Travis, K. R., Tessum, C. W., Marshall, J. D., Reinhart, W. F., Mikoviny, T., Müller, M., Wisthaler, A., Graus, M., Warneke, C., and de Gouw, J.: Emissions of C6 -C8 aromatic compounds in the United States: Constraints from tall tower and aircraft measurements, J. Geophys. Res.-Atmos., 120, 826-842, https://doi.org/10.1002/2014JD022627, 2015.

Hudman, R. C., Moore, N. E., Mebust, A. K., Martin, R. V., Russell, A. R., Valin, L. C., and Cohen, R. C.: Steps towards a mechanistic model of global soil nitric oxide emissions: implementation and space based-constraints, Atmos. Chem. Phys., 12, 7779-7795, https://doi.org/10.5194/acp-12-7779-2012, 2012.

Isbell, F., Reich, P. B., Tilman, D., Hobbie, S. E., Polasky, S., and Binder, S.: Nutrient enrichment, biodiversity loss, and consequent declines in ecosystem productivity, P. Natl. Acad. Sci. USA, 110, 11911-11916, https://doi.org/10.1073/pnas.1310880110, 2013.

Jacob, D. J.: Heterogeneous chemistry and tropospheric ozone, Atmos. Environ., 34, 2131-2159, https://doi.org/10.1016/S13522310(99)00462-8, 2000.

Jaegle, L., Steinberger, L., Martin, R. V., and Chance, K.: Global partitioning of NOx sources using satellite observations: Relative roles of fossil fuel combustion, biomass burning and soil emissions, Faraday Discuss., 130, 407-423, https://doi.org/10.1039/b502128f, 2005.

Jia, Y., Yu, G., Gao, Y., He, N., Wang, Q., Jiao, C., and Zuo, Y.: Global inorganic nitrogen dry deposition inferred from groundand space-based measurements, Scientific Reports, 6, 19810, https://doi.org/10.1038/srep19810, 2016.

Kanakidou, M., Myriokefalitakis, S., Daskalakis, N., Fanourgakis, G., Nenes, A., Baker, A. R., Tsigaridis, K., Mihalopoulos, N., Kanakidou, M., Myriokefalitakis, S., Daskalakis, N., Fanourgakis, G., Nenes, A., Baker, A. R., Tsigaridis, K., and Mihalopoulos, N.: Past, Present, and Future Atmospheric Nitrogen Deposition, J. Atmos. Sci., 73, 2039-2047, https://doi.org/10.1175/JAS-D-15-0278.1, 2016.

Kendall, M. G.: Rank Correlation Methods, 4 Edn., Charles Griffen, London, 1975.

Konovalov, I. B., Beekmann, M., Burrows, J. P., and Richter, A.: Satellite measurement based estimates of decadal changes in European nitrogen oxides emissions, Atmos. Chem. Phys., 8, 26232641, https://doi.org/10.5194/acp-8-2623-2008, 2008.

Konovalov, I. B., Beekmann, M., Richter, A., Burrows, J. P., and Hilboll, A.: Multi-annual changes of $\mathrm{NO}_{x}$ emissions in 
megacity regions: nonlinear trend analysis of satellite measurement based estimates, Atmos. Chem. Phys., 10, 8481-8498, https://doi.org/10.5194/acp-10-8481-2010, 2010.

Krotkov, N. A., McLinden, C. A., Li, C., Lamsal, L. N., Celarier, E. A., Marchenko, S. V., Swartz, W. H., Bucsela, E. J., Joiner, J., Duncan, B. N., Boersma, K. F., Veefkind, J. P., Levelt, P. F., Fioletov, V. E., Dickerson, R. R., He, H., Lu, Z., and Streets, D. G.: Aura OMI observations of regional $\mathrm{SO}_{2}$ and $\mathrm{NO}_{2}$ pollution changes from 2005 to 2015, Atmos. Chem. Phys., 16, 46054629, https://doi.org/10.5194/acp-16-4605-2016, 2016.

Kuhns, H., Knipping, E. M., and Vukovich, J. M.: Development of a United States-Mexico Emissions Inventory for the Big Bend Regional Aerosol and Visibility Observational (BRAVO) Study, J. Air Waste Manag. Assoc., 55, 677-692, 2005.

Lamarque, J.-F., Dentener, F., McConnell, J., Ro, C.-U., Shaw, M., Vet, R., Bergmann, D., Cameron-Smith, P., Dalsoren, S., Doherty, R., Faluvegi, G., Ghan, S. J., Josse, B., Lee, Y. H., MacKenzie, I. A., Plummer, D., Shindell, D. T., Skeie, R. B., Stevenson, D. S., Strode, S., Zeng, G., Curran, M., Dahl-Jensen, D., Das, S., Fritzsche, D., and Nolan, M.: Multi-model mean nitrogen and sulfur deposition from the Atmospheric Chemistry and Climate Model Intercomparison Project (ACCMIP): evaluation of historical and projected future changes, Atmos. Chem. Phys., 13, 7997-8018, https://doi.org/10.5194/acp-137997-2013, 2013.

Lamsal, L. N., Martin, R. V., van Donkelaar, A., Celarier, E. A., Bucsela, E. J., Boersma, K. F., Dirksen, R., Luo, C., and Wang, Y.: Indirect validation of tropospheric nitrogen dioxide retrieved from the OMI satellite instrument: Insight into the seasonal variation of nitrogen oxides at northern midlatitudes, J. Geophys. Res., 115, D05302, https://doi.org/10.1029/2009JD013351, 2010.

Lamsal, L. N., Martin, R. V, Padmanabhan, A., Van Donkelaar, A., Zhang, Q., Sioris, C. E., Chance, K., Kurosu, T. P., and Newchurch, M. J.: Application of satellite observations for timely updates to global anthropogenic NOx emission inventories, Geophys. Res. Lett., 38, L05810, https://doi.org/10.1029/2010GL046476, 2011.

Lee, H.-J., Kim, S.-W., Brioude, J., Cooper, O. R., Frost, G. J., Kim, C.-H., Park, R. J., Trainer, M., and Woo, J.H.: Transport of NOx in East Asia identified by satellite and in situ measurements and Lagrangian particle dispersion model simulations, J. Geophys. Res.-Atmos., 119, 2574-2596, https://doi.org/10.1002/2013JD021185, 2014.

Lee, H.-M., Paulot, F., Henze, D. K., Travis, K., Jacob, D. J., Pardo, L. H., and Schichtel, B. A.: Sources of nitrogen deposition in Federal Class I areas in the US, Atmos. Chem. Phys., 16, 525540, https://doi.org/10.5194/acp-16-525-2016, 2016.

Li, Y., Schichtel, B. A., Walker, J. T., Schwede, D. B., Chen, X., Lehmann, C. M. B., Puchalski, M. A., Gay, D. A., and Collett, J. L.: Increasing importance of deposition of reduced nitrogen in the United States, P. Natl. Acad. Sci. USA, 113, 5874-5879, https://doi.org/10.1073/pnas.1525736113, 2016.

Lin, J.-T., McElroy, M. B., and Boersma, K. F.: Constraint of anthropogenic $\mathrm{NO}_{x}$ emissions in China from different sectors: a new methodology using multiple satellite retrievals, Atmos. Chem. Phys., 10, 63-78, https://doi.org/10.5194/acp-10-632010, 2010.
Lin, M., Oki, T., Bengtsson, M., Kanae, S., Holloway, T., and Streets, D. G.: Long-range transport of acidifying substances in East Asia - Part II: Sourcereceptor relationships, Atmos. Environ., 42, 5956-5967, https://doi.org/10.1016/j.atmosenv.2008.03.039, 2008.

Liu, H., Jacob, D. J., Bey, I., and Yantosca, R. M.: Constraints from $210 \mathrm{~Pb}$ and $7 \mathrm{Be}$ on wet deposition and transport in a global threedimensional chemical tracer model driven by assimilated meteorological fields, J. Geophys. Res.-Atmos., 106, 12109-12128, https://doi.org/10.1029/2000JD900839, 2001.

Liu, L. L. and Greaver, T. L.: A review of nitrogen enrichment effects on three biogenic GHGs: the $\mathrm{CO}_{2}$ sink may be largely offset by stimulated $\mathrm{N}_{2} \mathrm{O}$ and $\mathrm{CH}_{4}$ emission, Ecol. Lett., 12, 11031117, 2009.

Lu, X., Jiang, H., Zhang, X., Liu, J., Zhang, Z., Jin, J., Wang, Y., $\mathrm{Xu}, \mathrm{J}$., and Cheng, M.: Estimated global nitrogen deposition using $\mathrm{NO}_{2}$ column density, Int. J. Remote Sens., 34, 8893-8906, https://doi.org/10.1080/01431161.2013.853894, 2013.

Lu, Z., Streets, D. G., de Foy, B., Lamsal, L. N., Duncan, B. N., and Xing, J.: Emissions of nitrogen oxides from US urban areas: estimation from Ozone Monitoring Instrument retrievals for 2005-2014, Atmos. Chem. Phys., 15, 10367-10383, https://doi.org/10.5194/acp-15-10367-2015, 2015.

Mann, H. B.: Non-parametric tests against trend, Econometrica, 13, 163-171, 1945.

Mao, J., Fan, S., Jacob, D. J., and Travis, K. R.: Radical loss in the atmosphere from $\mathrm{Cu}-\mathrm{Fe}$ redox coupling in aerosols, Atmos. Chem. Phys., 13, 509-519, https://doi.org/10.5194/acp-13-5092013, 2013.

Martin, R. V.: Global inventory of nitrogen oxide emissions constrained by space-based observations of $\mathrm{NO}_{2}$ columns, J. Geophys. Res., 108, 4537, https://doi.org/10.1029/2003JD003453, 2003.

Martin, R. V., Jacob, D. J., Yantosca, R. M., Chin, M., and Ginoux, P.: Global and regional decreases in tropospheric oxidants from photochemical effects of aerosols, J. Geophys. Res.-Atmos., 108, 4097, https://doi.org/10.1029/2002JD002622, 2003.

McLinden, C. A., Fioletov, V., Boersma, K. F., Krotkov, N., Sioris, C. E., Veefkind, J. P., and Yang, K.: Air quality over the Canadian oil sands: A first assessment using satellite observations, Geophys. Res. Lett., 39, L04804, https://doi.org/10.1029/2011GL050273, 2012.

Mijling, B., van der A, R. J., and Zhang, Q.: Regional nitrogen oxides emission trends in East Asia observed from space, Atmos. Chem. Phys., 13, 12003-12012, https://doi.org/10.5194/acp-1312003-2013, 2013.

Miyazaki, K., Eskes, H., Sudo, K., Boersma, K. F., Bowman, K., and Kanaya, Y.: Decadal changes in global surface $\mathrm{NO}_{x}$ emissions from multi-constituent satellite data assimilation, Atmos. Chem. Phys., 17, 807-837, https://doi.org/10.5194/acp-17-8072017, 2017.

Morino, Y., Ohara, T., Kurokawa, J., Kuribayashi, M., Uno, I., and Hara, H.: Temporal variations of nitrogen wet deposition across Japan from 1989 to 2008, J. Geophys. Res., 116, D06307, https://doi.org/10.1029/2010JD015205, 2011.

Mu, M., Randerson, J. T., van der Werf, G. R., Giglio, L., Kasibhatla, P., Morton, D., Collatz, G. J., DeFries, R. S., Hyer, E. J., Prins, E. M., Griffith, D. W. T., Wunch, D., Toon, G. C., Sherlock, V., and Wennberg, P. O.: Daily and 3-hourly variability in 
global fire emissions and consequences for atmospheric model predictions of carbon monoxide, J. Geophys. Res.-Atmos., 116, D24303, https://doi.org/10.1029/2011JD016245, 2011.

Murray, L. T., Jacob, D. J., Logan, J. A., Hudman, R. C., and Koshak, W. J.: Optimized regional and interannual variability of lightning in a global chemical transport model constrained by LIS/OTD satellite data, J. Geophys. Res.-Atmos., 117, D20307, https://doi.org/10.1029/2012JD017934, 2012.

Neuman, J. A., Parrish, D. D., Trainer, M., Ryerson, T. B., Holloway, J. S., Nowak, J. B., Swanson, A., Flocke, F., Roberts, J. M., Brown, S. S., Stark, H., Sommariva, R., Stohl, A., Peltier, R., Weber, R., Wollny, A. G., Sueper, D. T., Hubler, G., and Fehsenfeld, F. C.: Reactive nitrogen transport and photochemistry in urban plumes over the North Atlantic Ocean, J. Geophys. Res.Atmos., 111, D23S54, https://doi.org/10.1029/2005JD007010, 2006.

Nowlan, C. R., Martin, R. V., Philip, S., Lamsal, L. N., Krotkov, N. A., Marais, E. A., Wang, S., and Zhang, Q.: Global dry deposition of nitrogen dioxide and sulfur dioxide inferred from spacebased measurements, Global Biogeochem. Cy., 28, 1025-1043, https://doi.org/10.1002/2014GB004805, 2014.

Olivier, J. G. J., Van Aardenne, J. A., Dentener, F. J., Pagliari, V., Ganzeveld, L. N., and Peters, J. A. H. W.: Recent trends in global greenhouse gas emissions: regional trends 1970-2000 and spatial distributionof key sources in 2000, Environ. Sci., 2, 81-99, https://doi.org/10.1080/15693430500400345, 2005.

Park, R. J., Jacob, D. J., Field, B. D., and Yantosca, R. M.: Natural and transboundary pollution influences on sulfate-nitrate-ammonium aerosols in the United States: Implications for policy, J. Geophys. Res., 109, D15204, https://doi.org/10.1029/2003JD004473, 2004.

Paulot, F., Crounse, J. D., Kjaergaard, H. G., Kroll, J. H., Seinfeld, J. H., and Wennberg, P. O.: Isoprene photooxidation: new insights into the production of acids and organic nitrates, Atmos. Chem. Phys., 9, 1479-1501, https://doi.org/10.5194/acp-9-14792009, 2009a.

Paulot, F., Crounse, J. D., Kjaergaard, H. G., Kürten, A., St Clair, J. M., Seinfeld, J. H., and Wennberg, P. O.: Unexpected epoxide formation in the gas-phase photooxidation of isoprene, Science, 325, 730-733, https://doi.org/10.1126/science.1172910, $2009 \mathrm{~b}$.

Reay, D. S., Dentener, F., Smith, P., Grace, J., and Feely, R. A.: Global nitrogen deposition and carbon sinks, Nat. Geosci., 1, 430-437, 2008.

Reichle, R. H., Draper, C. S., Liu, Q., Girotto, M., Mahanama, S. P. P., Koster, R. D., De Lannoy, G. J. M., Reichle, R. H., Draper, C. S., Liu, Q., Girotto, M., Mahanama, S. P. P., Koster, R. D., and Lannoy, G. J. M. De: Assessment of MERRA-2 Land Surface Hydrology Estimates, J. Climate, 30, 2937-2960, https://doi.org/10.1175/JCLI-D-16-0720.1, 2017.

Reis, S., Pinder, R. W., Zhang, M., Lijie, G., and Sutton, M. A.: Reactive nitrogen in atmospheric emission inventories, Atmos. Chem. Phys., 9, 7657-7677, https://doi.org/10.5194/acp-9-76572009, 2009.

Richter, A., Eyring, V., Burrows, J. P., Bovensmann, H., Lauer, A., Sierk, B., and Crutzen, P. J.: Satellite measurements of $\mathrm{NO}_{2}$ from international shipping emissions, Geophys. Res. Lett., 31, L23110, https://doi.org/10.1029/2004GL020822, 2004.

Richter, A., Burrows, J. P., Nüss, H., Granier, C., and Niemeier, U.: Increase in tropospheric nitrogen dioxide over China observed from space, Nature, 437, 129-132, https://doi.org/10.1038/nature04092, 2005.

Rienecker, M. M., Suarez, M. J., Gelaro, R., Todling, R., Bacmeister, J., Liu, E., Bosilovich, M. G., Schubert, S. D., Takacs, L., Kim, G.-K., Bloom, S., Chen, J., Collins, D., Conaty, A., da Silva, A., Gu, W., Joiner, J., Koster, R. D., Lucchesi, R., Molod, A., Owens, T., Pawson, S., Pegion, P., Redder, C. R., Reichle, R., Robertson, F. R., Ruddick, A. G., Sienkiewicz, M., Woollen, J., Rienecker, M. M., Suarez, M. J., Gelaro, R., Todling, R., Julio Bacmeister, Liu, E., Bosilovich, M. G., Schubert, S. D., Takacs, L., Kim, G.-K., Bloom, S., Chen, J., Collins, D., Conaty, A., Silva, A. da, Gu, W., Joiner, J., Koster, R. D., Lucchesi, R., Molod, A., Owens, T., Pawson, S., Pegion, P., Redder, C. R., Reichle, R., Robertson, F. R., Ruddick, A. G., Sienkiewicz, M., and Woollen, J.: MERRA: NASA's Modern-Era Retrospective Analysis for Research and Applications, J. Climate, 24, 3624-3648, https://doi.org/10.1175/JCLI-D-11-00015.1, 2011.

Russell, A. R., Valin, L. C., and Cohen, R. C.: Trends in OMI $\mathrm{NO}_{2}$ observations over the United States: effects of emission control technology and the economic recession, Atmos. Chem. Phys., 12, 12197-12209, https://doi.org/10.5194/acp-12-121972012, 2012.

Sanderson, M. G., Dentener, F. J., Fiore, A. M., Cuvelier, C., Keating, T. J., Zuber, A., Atherton, C. S., Bergmann, D. J., Diehl, T., Doherty, R. M., Duncan, B. N., Hess, P., Horowitz, L. W., Jacob, D. J., Jonson, J. E., Kaminski, J. W., Lupu, A., MacKenzie, I. A., Mancini, E., Marmer, E., Park, R., Pitari, G., Prather, M. J., Pringle, K. J., Schroeder, S., Schultz, M. G., Shindell, D. T., Szopa, S., Wild, O., and Wind, P.: A multi-model study of the hemispheric transport and deposition of oxidised nitrogen, Geophys. Res. Lett., 35, L17815, https://doi.org/10.1029/2008GL035389, 2008.

Sen, P. K.: Estimates of the Regression Coefficient Based on Kendall's Tau, J. Am. Stat. Assoc., 63, 1379-1389, https://doi.org/10.1080/01621459.1968.10480934, 1968.

Sickles II, J. E. and Shadwick, D. S.: Changes in air quality and atmospheric deposition in the eastern United States: 1990-2004, J. Geophys. Res., 112, D17301, https://doi.org/10.1029/2006JD007843, 2007.

Sickles II, J. E. and Shadwick, D. S.: Air quality and atmospheric deposition in the eastern US: 20 years of change, Atmos. Chem. Phys., 15, 173-197, https://doi.org/10.5194/acp-15-1732015, 2015.

Souri, A. H., Choi, Y., Jeon, W., Li, X., Pan, S., Diao, L., and Westenbarger, D. A.: Constraining NOx emissions using satellite $\mathrm{NO}_{2}$ measurements during 2013 DISCOVERAQ Texas campaign, Atmos. Environ., 131, 371-381, https://doi.org/10.1016/j.atmosenv.2016.02.020, 2016.

Stavrakou, T., Müller, J.-F., Boersma, K. F., De Smedt, I., and van $\operatorname{der}$ A, R. J.: Assessing the distribution and growth rates of NOx emission sources by inverting a 10-year record of $\mathrm{NO}_{2}$ satellite columns, Geophys. Res. Lett., 35, L10801, https://doi.org/10.1029/2008GL033521, 2008.

Stavrakou, T., Müller, J.-F., Boersma, K. F., van der A, R. J., Kurokawa, J., Ohara, T., and Zhang, Q.: Key chemical $\mathrm{NO}_{x}$ sink uncertainties and how they influence top-down emissions of nitrogen oxides, Atmos. Chem. Phys., 13, 9057-9082, https://doi.org/10.5194/acp-13-9057-2013, 2013. 
Stettler, M. E. J., Eastham, S., and Barrett, S. R. H.: Air quality and public health impacts of UK airports, Part I: Emissions, Atmos. Environ., 45, 5415-5424, https://doi.org/10.1016/j.atmosenv.2011.07.012, 2011.

Streets, D. G., Canty, T., Carmichael, G. R., de Foy, B., Dickerson, R. R., Duncan, B. N., Edwards, D. P., Haynes, J. A., Henze, D. K., Houyoux, M. R., Jacob, D. J., Krotkov, N. A., Lamsal, L. N., Liu, Y., Lu, Z., Martin, R. V., Pfister, G. G., Pinder, R. W., Salawitch, R. J., and Wecht, K. J.: Emissions estimation from satellite retrievals: A review of current capability, Atmos. Environ., 77, 1011-1042, https://doi.org/10.1016/j.atmosenv.2013.05.051, 2013.

Tanimoto, H., Sawa, Y., Matsueda, H., Uno, I., Ohara, T., Yamaji, K., Kurokawa, J., and Yonemura, S.: Significant latitudinal gradient in the surface ozone spring maximum over East Asia, Geophys. Res. Lett., 32, L21805, https://doi.org/10.1029/2005GL023514, 2005.

Templer, P. H., Pinder, R. W., and Goodale, C. L.: Effects of nitrogen deposition on greenhouse-gas fluxes for forests and grasslands of North America, Front. Ecol. Environ., 10, 547-553, https://doi.org/10.1890/120055, 2012.

Travis, K. R., Jacob, D. J., Fisher, J. A., Kim, P. S., Marais, E. A., Zhu, L., Yu, K., Miller, C. C., Yantosca, R. M., Sulprizio, M. P., Thompson, A. M., Wennberg, P. O., Crounse, J. D., St. Clair, J. M., Cohen, R. C., Laughner, J. L., Dibb, J. E., Hall, S. R., Ullmann, K., Wolfe, G. M., Pollack, I. B., Peischl, J., Neuman, J. A., and Zhou, X.: Why do models overestimate surface ozone in the Southeast United States?, Atmos. Chem. Phys., 16, 1356113577, https://doi.org/10.5194/acp-16-13561-2016, 2016.

Valin, L. C., Russell, A. R., Hudman, R. C., and Cohen, R. C.: Effects of model resolution on the interpretation of satellite $\mathrm{NO}_{2}$ observations, Atmos. Chem. Phys., 11, 11647-11655, https://doi.org/10.5194/acp-11-11647-2011, 2011.

Van Damme, M., Clarisse, L., Heald, C. L., Hurtmans, D., Ngadi, Y., Clerbaux, C., Dolman, A. J., Erisman, J. W., and Coheur, P. F.: Global distributions, time series and error characterization of atmospheric ammonia $\left(\mathrm{NH}_{3}\right)$ from IASI satellite observations, Atmos. Chem. Phys., 14, 2905-2922, https://doi.org/10.5194/acp14-2905-2014, 2014.

van der A, R. J., Eskes, H. J., Boersma, K. F., van Noije, T. P. C., Van Roozendael, M., De Smedt, I., Peters, D. H. M. U., and Meijer, E. W.: Trends, seasonal variability and dominant NOx source derived from a ten year record of $\mathrm{NO}_{2}$ measured from space, J. Geophys. Res., 113, D04302, https://doi.org/10.1029/2007JD009021, 2008.

van Donkelaar, A., Martin, R. V., Leaitch, W. R., Macdonald, A. M., Walker, T. W., Streets, D. G., Zhang, Q., Dunlea, E. J., Jimenez, J. L., Dibb, J. E., Huey, L. G., Weber, R., and Andreae, M. O.: Analysis of aircraft and satellite measurements from the Intercontinental Chemical Transport Experiment (INTEX-B) to quantify long-range transport of East Asian sulfur to Canada, Atmos. Chem. Phys., 8, 2999-3014, https://doi.org/10.5194/acp-8-29992008, 2008.

Veefkind, J. P., Aben, I., McMullan, K., Förster, H., de Vries, J., Otter, G., Claas, J., Eskes, H. J., de Haan, J. F., Kleipool, Q., van Weele, M., Hasekamp, O., Hoogeveen, R., Landgraf, J., Snel, R., Tol, P., Ingmann, P., Voors, R., Kruizinga, B., Vink, R., Visser, H., and Levelt, P. F.: TROPOMI on the ESA Sentinel-5 Precursor: A GMES mission for global observations of the atmospheric composition for climate, air quality and ozone layer applications, Remote Sens. Environ., 120, 70-83, https://doi.org/10.1016/j.rse.2011.09.027, 2012.

Vet, R., Artz, R. S., Carou, S., Shaw, M., Ro, C.-U., Aas, W., Baker, A., Bowersox, V. C., Dentener, F., Galy-Lacaux, C., Hou, A., Pienaar, J. J., Gillett, R., Forti, M. C., Gromov, S., Hara, H., Khodzher, T., Mahowald, N. M., Nickovic, S., Rao, P. S. P., and Reid, N. W.: A global assessment of precipitation chemistry and deposition of sulfur, nitrogen, sea salt, base cations, organic acids, acidity and pH, and phosphorus, Atmos. Environ., 93, $3-$ 100, https://doi.org/10.1016/j.atmosenv.2013.10.060, 2014.

Vinken, G. C. M., Boersma, K. F., Maasakkers, J. D., Adon, M., and Martin, R. V.: Worldwide biogenic soil $\mathrm{NO}_{x}$ emissions inferred from $\mathrm{OMI} \mathrm{NO}_{2}$ observations, Atmos. Chem. Phys., 14, 10363 10381, https://doi.org/10.5194/acp-14-10363-2014, 2014.

Walker, T. W., Martin, R. V., van Donkelaar, A., Leaitch, W. R., MacDonald, A. M., Anlauf, K. G., Cohen, R. C., Bertram, T. H., Huey, L. G., Avery, M. A., Weinheimer, A. J., Flocke, F. M., Tarasick, D. W., Thompson, A. M., Streets, D. G., and Liu, X.: Trans-Pacific transport of reactive nitrogen and ozone to Canada during spring, Atmos. Chem. Phys., 10, 8353-8372, https://doi.org/10.5194/acp-10-8353-2010, 2010.

Wang, Y. H., Jacob, D. J., and Logan, J. A.: Global simulation of tropospheric O-3-NOx-hydrocarbon chemistry 1. Model formulation, J. Geophys. Res., 103, 10713-10725, https://doi.org/10.1029/98JD00158, 1998.

Wesely, M. L.: Parameterization of surface resistances to gaseous dry deposition in regional-scale numerical models, Atmos. Environ., 23, 1293-1304, https://doi.org/10.1016/00046981(89)90153-4, 1989.

World Health Organization: WHO Air Quality Guidelines for Europe, 2nd Edn., available at: http://www.euro.who.int/en/ publications/abstracts/air-quality-guidelines-for-europe (last access: 28 October 2016), 2000.

Zbieranowski, A. L. and Aherne, J.: Long-term trends in atmospheric reactive nitrogen across Canada: 1988-2007, Atmos. Environ., 45, 5853-5862, https://doi.org/10.1016/j.atmosenv.2011.06.080, 2011.

Zhang, L., Gong, S., Padro, J., and Barrie, L.: A size-segregated particle dry deposition scheme for an atmospheric aerosol module, Atmos. Environ., 35, 549-560, https://doi.org/10.1016/S13522310(00)00326-5, 2001.

Zhang, L., Jacob, D. J., Boersma, K. F., Jaffe, D. A., Olson, J. R., Bowman, K. W., Worden, J. R., Thompson, A. M., Avery, M. A., Cohen, R. C., Dibb, J. E., Flock, F. M., Fuelberg, H. E., Huey, L. G., McMillan, W. W., Singh, H. B., and Weinheimer, A. J.: Transpacific transport of ozone pollution and the effect of recent Asian emission increases on air quality in North America: an integrated analysis using satellite, aircraft, ozonesonde, and surface observations, Atmos. Chem. Phys., 8, 6117-6136, https://doi.org/10.5194/acp-8-6117-2008, 2008.

Zhang, L., Jacob, D. J., Knipping, E. M., Kumar, N., Munger, J. W., Carouge, C. C., van Donkelaar, A., Wang, Y. X., and Chen, D.: Nitrogen deposition to the United States: distribution, sources, and processes, Atmos. Chem. Phys., 12, 4539-4554, https://doi.org/10.5194/acp-12-4539-2012, 2012.

Zhang, Q., Streets, D. G., He, K., Wang, Y., Richter, A., Burrows, J. P., Uno, I., Jang, C. J., Chen, D., Yao, Z., and Lei, Y.: NOx emission trends for China, 1995-2004: The view from the 
ground and the view from space, J. Geophys. Res., 112, D22306, https://doi.org/10.1029/2007JD008684, 2007.

Zhang, Q., Streets, D. G., Carmichael, G. R., He, K. B., Huo, H., Kannari, A., Klimont, Z., Park, I. S., Reddy, S., Fu, J. S., Chen, D., Duan, L., Lei, Y., Wang, L. T., and Yao, Z. L.: Asian emissions in 2006 for the NASA INTEX-B mission, Atmos. Chem. Phys., 9, 5131-5153, https://doi.org/10.5194/acp-9-5131-2009, 2009.

Zhao, Y., Zhang, L., Pan, Y., Wang, Y., Paulot, F., and Henze, D. K.: Atmospheric nitrogen deposition to the northwestern Pacific: seasonal variation and source attribution, Atmos. Chem. Phys., 15, 10905-10924, https://doi.org/10.5194/acp-15-109052015, 2015.

Zhao, Y., Zhang, L., Chen, Y., Liu, X., Xu, W., Pan, Y., and Duan, L.: Atmospheric nitrogen deposition to China: A model analysis on nitrogen budget and critical load exceedance, Atmos. Environ., 153, 32-40, https://doi.org/10.1016/j.atmosenv.2017.01.018, 2017.

Zien, A. W., Richter, A., Hilboll, A., Blechschmidt, A.-M., and Burrows, J. P.: Systematic analysis of tropospheric $\mathrm{NO}_{2}$ longrange transport events detected in GOME-2 satellite data, Atmos. Chem. Phys., 14, 7367-7396, https://doi.org/10.5194/acp14-7367-2014, 2014.
Zoogman, P., Liu, X., Suleiman, R. M., Pennington, W. F., Flittner, D. E., Al-Saadi, J. A., Hilton, B. B., Nicks, D. K., Newchurch, M. J., Carr, J. L., Janz, S. J., Andraschko, M. R., Arola, A., Baker, B. D., Canova, B. P., Chan Miller, C., Cohen, R. C., Davis, J. E., Dussault, M. E., Edwards, D. P., Fishman, J., Ghulam, A., González Abad, G., Grutter, M., Herman, J. R., Houck, J., Jacob, D. J., Joiner, J., Kerridge, B. J., Kim, J., Krotkov, N. A., Lamsal, L., Li, C., Lindfors, A., Martin, R. V., McElroy, C. T., McLinden, C., Natraj, V., Neil, D. O., Nowlan, C. R., O’Sullivan, E. J., Palmer, P. I., Pierce, R. B., Pippin, M. R., Saiz-Lopez, A., Spurr, R. J. D., Szykman, J. J., Torres, O., Veefkind, J. P., Veihelmann, B., Wang, H., Wang, J., and Chance, K.: Tropospheric emissions: Monitoring of pollution (TEMPO), J. Quant. Spectrosc. Ra., 186, 17-39, https://doi.org/10.1016/j.jqsrt.2016.05.008, 2017. 